\title{
SELEÇÃO E CARACTERIZAÇÃO DE Metarhizium anisopliae VISANDO AO CONTROLE DE Mahanarva fimbriolata (HEMIPTERA: CERCOPIDAE) EM CANA-DE-AÇÚCAR
}

\author{
Daniella Macedo
}

\begin{abstract}
Tese apresentada à Escola Superior de Agricultura "Luiz de Queiroz", Universidade de São Paulo, para obtenção do título de Doutor em Ciências, Área de Concentração: Entomologia.
\end{abstract}

P I R A C I C A B A

Estado de São Paulo - Brasil

Janeiro - 2005 


\title{
SELEÇÃO E CARACTERIZAÇÃO DE Metarhizium anisopliae VISANDO AO CONTROLE DE Mahanarva fimbriolata (HEMIPTERA: CERCOPIDAE) EM CANA-DE-AÇÚCAR
}

\author{
DANiELla MACEDO \\ Engenheiro Agrônomo
}

Orientador: Prof. Dr. SÉRgio Batista Alves

\begin{abstract}
Tese apresentada à Escola Superior de Agricultura "Luiz de Queiroz", Universidade de São Paulo, para obtenção do título de Doutor em Ciências, Área de Concentração: Entomologia.
\end{abstract}

P I R A C I C A B A

Estado de São Paulo - Brasil

Janeiro - 2005 
Dados Internacionais de Catalogação na Publicação (CIP)
DIVISÃO DE BIBLIOTECA E DOCUMENTAÇÃO - ESALQ/USP

Macedo, Daniella

Seleção e caracterização de Metarhizium anisopliae visando ao controle de Mahanarva fimbriolata (Hemiptera: Cercopidae) em cana-de-açúcar / Daniella Macedo. - - Piracicaba, 2005.

87 p. : il.

Tese (Doutorado) - - Escola Superior de Agricultura Luiz de Queiroz, 2005.

Bibliografia.

1. Cana-de-açúcar 2. Cigarrinha-da-raiz 3. Controle biológico (Fitossanidade) 4. Diversidade genética 5. DNA 6. Fungo entomopatogênico 7. Marcador molecular I. Título

CDD 633.61 
Aos meus pais, Newton e Maria Inês; ao meu irmão, Rodrigo e à minha tia, Dorinha, pelo apoio, incentivo e exemplo em minha vida, pessoal e profissional,

\section{OFEREÇO E DEDICO}




\section{AGRADECIMENTOS}

Ao Prof. Dr. Sérgio Batista Alves, pela oportunidade em desenvolver esse trabalho; pela orientação, incentivo e amizade durante nosso convívio.

À bióloga Solange Aparecida Vieira pela grande amizade e valorosa colaboração nos experimento de laboratório.

Aos amigos do laboratório de Patologia e Controle Microbiano de Insetos: Rogério (Phyto), Luciana, Melissa, Juan, Luiz Fernando, Giuliano (Kutuk), Daniela (Náufraga), Gabriel (Goma).

Aos Professores do curso de Pós-graduação em Entomologia da ESALQ -USP, pelos ensinamentos e colaboração, em especial ao Professor Dr. João Roberto Spotti Lopes por permitir que as análises de RAPD fossem feitas no Laboratório de Vetores de Fitopatógenos.

Ao pessoal do Laboratório de Vetores de Fitopatógenos pela colaboração durante o período em que foram feitas as análises de RAPD. 
Aos funcionários do Setor de Entomologia da ESALQ-USP pela amizade e apoio, em particular à Ana Gabriela Brancalhão Fabretti (secretária).

À Professora Maria Helena P. Fungaro, da Universidade Federal de Londrina, pelos ensinamentos sobre as análises de DNA.

À doutoranda Mayra Kassawara Martins pelo auxílio na análise de RAPD.

À doutora Maria Imaculada Zucchi pela leitura e sugestões na interpretação dos resultados da análise de RAPD.

Às amigas Lili Stipp, Letícia (Padrão) Altafin, Adriana Pires por estarem presentes me apoiando e incentivando.

Ao Marcelo Aguiar Abritta, pelo carinho, apoio, dedicação, incentivo e por estar ao meu lado em horas difíceis e alegres.

A todos que contribuíram na realização desse trabalho e que, de alguma forma me apoiaram e incentivaram.

Ao Conselho Nacional de Pesquisa e Desenvolvimento Tecnológico (CNPq) pela bolsa de estudos que possibilitou a execução deste trabalho. 


\section{SUMÁRIO}

Página

LISTA DE FIGURAS ............................................................................. ix

LISTA DE TABELAS ........................................................................... xii

RESUMO

SUMMARY

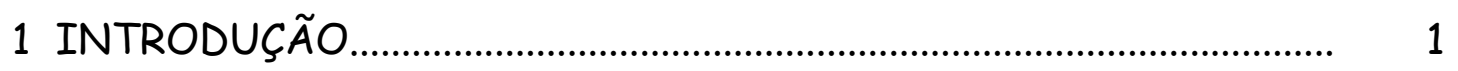

2 REVISÃO DE LITERATURA .......................................................... 4

2.1 Mahanarva fimbriolata........................................................................ 4

2.1.1 Controle de Mahanarva fimbriolata.................................................... 8

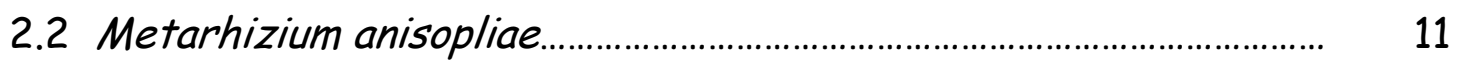

2.3 RAPD (Random Amplified Polymorphic DNA).................................... 17

3 MATERIALE MÉTODOS................................................................. 24

3.1 Patogenicidade de isolados de Metarhizium anisopliae a Mahanarva fimbriolata...................................................................... 24

3.1.1 Obtenção das ninfas de Mahanarva fimbriolata............................. 26

3.1.2 Produção dos isolados de Metarhizium anisopliae (Metsch.) Sorokin. 


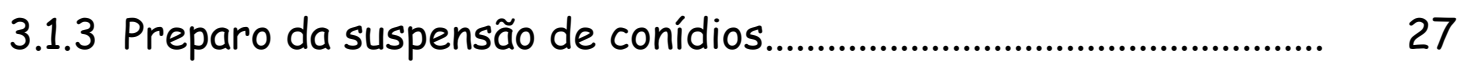

3.1.4 Produção dos isolados de Metarhizium anisopliae pelo processo da bandeja.

3.2 Caracterização morfológica e genética dos isolados de Metarhizium anisopliae.

3.2.1 Caracterização morfológica............................................................... 31

3.2.2 Caracterização genética................................................................. 32

3.2.2.1 Produção dos isolados de Metarhizium anisopliae, para aplicação da técnica de RAPD (Random Amplified Polymorphic DNA).

3.2.2.2 Extração do DNA genômico

3.2.2.3 Amplificação RAPD (Random Amplified Polymorphic DNA)...... 34

4 RESULTADOS EDISCUSSÃO.

4.1 Patogenicidade de isolados de Metarhizium anisopliae a Mahanarva fimbriolata.

4.1.1 Produção dos isolados de Metarhizium anisopliae pelo método da bandeja...

4.2 Caracterização morfológica e genética dos isolados de Metarhizium anisopliae.

4.2.1 Caracterização morfológica.............................................................. 45

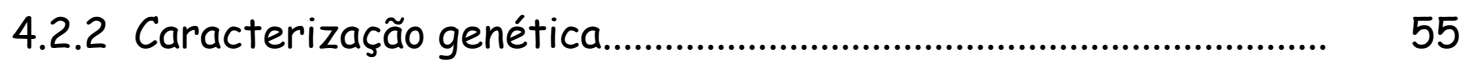

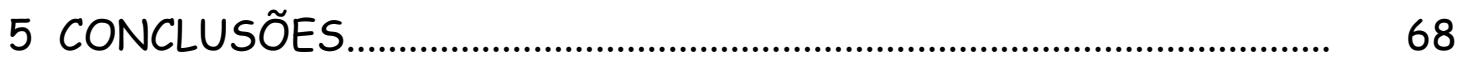


Página

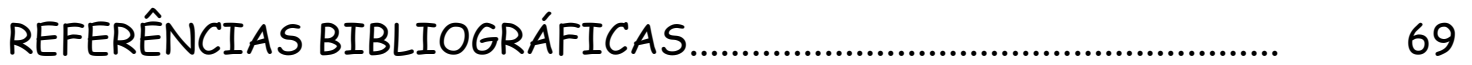




\section{LISTA DE FIGURAS}

Página

1 A) Ninfas de Mahanarva fimbriolata apresentando espuma característica; B) Aspecto dos tratamento separados em bandejas...

2 Bandejas utilizadas para a produção do fungo

3 Mortalidade corrigida (\%) de Mahanarva fimbriolata causada pelos diferentes isolados de Metarhizium anisopliae.

4 A) Ninfa e adulto de Mahanarva fimbriolata infectados com Metarhizium anisopliae; B) Interferência do fungo Metarhizium anisopliae no processo de ecdise de ninfa de Mahanarva fimbriolata

5 Características culturais de Metarhizium anisopliae isolado ESALQ 1037 (A) e isolado IBCB-348 (B) aos oito dias após a inoculação

6 Crescimento e esporulação das colônias de Metarhizium anisopliae aos após oito dias da inoculação em meio de cultura. 
7 A) Conidióforo de Metarhizium anisopliae (Alves, 1998); B) Foto do conidióforo do isolado ESALQ 1037 de Metarhizium anisopliae.

8 Estimativa da concentração de DNA genômico em gel de eletroforese colorido com brometo de etídio, detectando a presença de RNA de fita dupla em onze dos vinte isolados de Metarhizium anisopliae. (Sequiência dos isolados no gel: DNA padrão, concentração 1, 2 e 3; isolados: ESALQ 1037 (4); ESALQ E9 (5); IBCB-348 (6); IBCB-353 (7); IBCB-333 (8); IBCB-391 (9); IBCB-380 (10); IBCB-334 (11); IBCB-345 (12); IBCB-374 (13); ESALQ 1294 (14); ESALQ 1204 (15); ESALQ 1286 (16); ESALQ 319 (17); ESALQ PL43 (18); ESALQ 935 (19); ESALQ PL49 (20); ESALQ PL26 (21); ESALQ 1301 (22) e IBCB-384 (23))

9 Características culturais de isolados com presença de RNA de fita dupla em meio B.D.A. (A) e em meio M.C. (B)

10 Perfis de RAPD dos isolados de Metarhizium anisopliae, ESALQ 1037: ESALQ E9; IBCB-348; IBCB-353; IBCB-333; IBCB-391; IBCB-380; IBCB-334; IBCB-345; IBCB-374; ESALQ 1294; ESALQ 1204; ESALQ 1286; ESALQ 319; ESALQ PL43; ESALQ 935; ESALQ PL49; ESALQ PL26; ESALQ 1301 e IBCB-384, obtidos com os "primers" G-13, AX-17 e P-09, respectivamente. 
11 Dendrograma construído pelo método de agrupamento UPGMA a partir da matriz de similaridade obtida pelo coeficiente Dice ilustrando a relação entre 20 isolados de Metarhizium anisopliae....

12 Características morfológicas de colônias de Metarhizium anisopliae isolados ESALQ 1301, ESALQ E9 e IBCB-374 com oito dias de incubação $\left(26 \pm 1^{\circ} \mathrm{C} ; \quad 80 \pm 5 \%\right.$ UR; 12 horas de 62 fotofase). 


\section{LISTA DE TABELAS}

Página

1 Isolados de Metarhizium anisopliae testados para o controle de Mahanarva fimbriolata

2 Sequiência dos "primers" selecionados para utilização no RAPD......

3 Isolados, hospedeiro original, local de origem e mortalidade corrigida (\%) de Metarhizium anisopliae a ninfas de Mahanarva fimbriolata..

4 Média do número de conídios por grama dos isolados de Metarhizium anisopliae produzidos massalmente pelo método de bandeja.

5 Comprimento médio dos conídios dos isolados de Metarhizium anisopliae. 


\section{SELEÇÃO E CARACTERIZAÇÃO DE Metarhizium anisopliae VISANDO AO CONTROLE DE Mahanarva fimbriolata (HEMIPTERA: CERCOPIDAE) EM CANA-DE-AÇÚCAR}

Autor: DANIELLA MACEDO

Orientador: Prof. Dr. SÉRGIO BATISTA ALVES

\section{RESUMO}

O objetivo da pesquisa foi selecionar isolados de Metarhizium anisopliae patogênicos para cigarrinha-da-raiz, Mahanarva fimbriolata, e caracterizá-los morfológica e geneticamente, por meio de técnicas de análise de DNA (RAPD). A seleção foi feita em laboratório, utilizando ninfas coletadas a campo que foram pulverizadas com o fungo e mantidas nas raízes de mudas de cana-de-açúcar. A mortalidade corrigida, ao quinto dia após a inoculação, variou de 10,5 a $60 \%$. Verificou-se que todos os isolados apresentaram coloração das colônias variando de verde acinzentado ao verde escuro, com crescimento de $28 \mathrm{~mm}$ para o isolado IBCB-353 à $38 \mathrm{~mm}$ para o isolado IBCB-348. O comprimento dos conídios não teve influência na

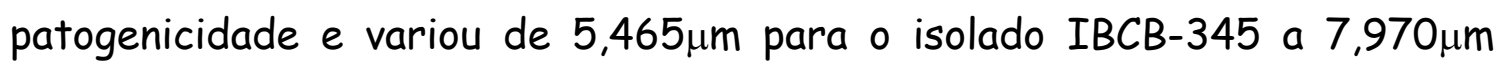


para o isolado ESALQ 1301 sendo que todos pertencem à subespécie anisopliae. Constatou-se a presença de RNA de fita dupla em onze dos vinte isolados, mas não houve relação entre a presença desta banda e sua patogenicidade para M. fimbriolata. Foi possivel separar os isolados em dois grupos $(A$ e B ) com $72,5 \%$ de similaridade, sendo observada a composição de dois subgrupos (B1 e B2), com $77,5 \%$ de similaridade, dentro do grupo B. A alta similaridade entre os dois grupos e dentro de cada um deles, indicou que os isolados pertencem à mesma subespécie, reforçando o que foi concluído com a caracterização morfológica. O método utilizado confirma a grande diversidade genética da espécie M. anisopliae, porém, não reflete sua similaridade de patogenicidade a ninfas de M. fimbriolata, pois os dois isolados mais patogênicos (IBCB-384 e ICBC-348) foram dispostos em grupos diferentes. Não se observou um padrão específico de agrupamento entre isolados oriundos da mesma região ou hospedeiro, ou seja, a diversidade genética parece ser independente do local de origem do fungo, como seria esperado com um patógeno que, em geral, tem revelado alto grau de especialização ao hospedeiro. 


\title{
SELECTION AND CARACTERIZATION OF Metarhizium anisopliae FOR THE CONTROL OF Mahanarva fimbriolata (HEMIPTERA: CERCOPIDAE) IN SUGAR-CANE
}

\author{
Author: DANIELLA MACEDO \\ Adviser: Prof. Dr. SÉRGIO BATISTA ALVES
}

\section{SUMMARY}

This research was carried out to evaluate the pathogenicity of isolates of the entomopatogenic fungus Metarhizium anisopliae against the spittlebug, Mahanarva fimbriolata, and to characterize them morphologically and genetically through RAPD method. The selection was made under laboratory condition, using nymphs collected at field. The fungus was sprayed on the nymphs by a Potter tower (15 pounds/pol ${ }^{2}$ ) and then, they were maintained in roots of sugar-cane seedlings. The mortality was evaluated 5 days after the inoculation, ranging from 10.5 to $60 \%$. The colonies' color varied from grayish green to dark green and the colonies diameter ranged from $28 \mathrm{~mm}$ (isolate IBCB-353) to $38 \mathrm{~mm}$ (isolate IBCB348). The conidia length ranged from $5.465 \mu \mathrm{m}$ for the isolate IBCB-345 to 
$7.970 \mu \mathrm{m}$ for the isolate ESALQ 1301. With those results it could be concluded that all the studied strains belong to the subspecies anisopliae. The size did not have influence in the pathogenicity of the isolate. It was evidenced presence of double-stranded RNA (virus) in eleven out of the twenty isolates tested, but it did not have relation between the presence of the virus and its pathogenicity for M. fimbriolata. It was possible to separate isolates in two groups (A and B) with $72.5 \%$ of similarity, being observed the composition of two sub-groups (B1 and B2), with $77.5 \%$ of similarity, inside of group B. The high similarity between the two groups and inside of each one indicated that the isolates belong to the same subspecies, confirming what it was concluded with the morphologic characterization. The used method confirms the great genetic diversity of species M. anisopliae, however, does not reflect its similarity of pathogenicity the nymphs of M. fimbriolata, therefore the two isolated most pathogenic (IBCB-384 and ICBC-348) were located in different fenetic groups. In the present study a specific standard of grouping between isolated deriving of the same region or host was not observed, or either, the genetic diversity seems to be independent on the fungus origin, as it would be expected from a pathogen that, in general, shows high degree of specialization to the host. 


\section{INTRODUÇÃO}

A cultura da cana-de-açúcar ocupa cerca de 5,57 milhões de hectares de área colhida no Brasil, com produção de 411 milhões de toneladas de cana em 2004, e movimenta um grande volume de negócios relacionados à exportação de açúcar e ao programa nacional de álcool (IBGE, 2004). O Estado de São Paulo é responsável por $58 \%$ da produção nacional, com cerca de 49,5\% da área total de cana-de-açúcar plantada no país.

Apesar da grande importância da cultura para o Brasil, parte da produção ainda é perdida devido aos danos causados por várias pragas, dentre as quais, as cigarrinhas pertencentes ao gênero Mahanarva. Até os últimos anos, a cigarrinha-da-raiz, Mahanarva fimbriolata, foi considerada de importância econômica somente em algumas plantações do Nordeste, causando perdas de 30 a $60 \%$ da produção em Sergipe e na Bahia, respectivamente (Mendonça et al., 1996).

No Estado de São Paulo esta praga sempre ocorreu esporadicamente, sem causar dano econômico, porém, com a proibição da queima da cana-de-açúcar por meio do Decreto-lei Estadual nº. 42.056/97 e com o conseqüente aumento das áreas de colheita mecanizada de cana "crua", as infestações de M. fimbriolata se tornaram mais elevadas, constituindo-se, atualmente, em um dos mais preocupantes problemas para a 
cultura, especialmente em locais de temperatura elevada e alta umidade proporcionada pela abundante cobertura vegetal deixada no solo (Macedo et al., 1997: Dinardo-Miranda et al., 1999; Dinardo-Miranda et al., 2001; Dinardo-Miranda et al., 2004a).

Apesar dos benefícios ambientais trazidos por esse novo sistema de colheita, novos desafios técnicos e econômicos surgiram e deverão ser solucionados para que se mantenha viável essa importante cultura para o Estado de São Paulo. A ocorrência de altas populações de cigarrinha-da-raiz (M. fimbriolata) em áreas de colheita de cana "crua" é um problema sério a ser equacionado nesse sistema de colheita, tanto pelos danos econômicos que ocasiona, se não controladas, quanto pelas limitadas informações disponíveis sobre as alternativas de controle (Macedo \& Macedo, 2004).

Poucas pesquisas foram realizadas no Estado de São Paulo, devido à baixa expressão econômica dessa praga. São conhecidos apenas alguns aspectos de sua flutuação populacional (Mendes, 1978) e de controle, pela utilização do fungo M. anisopliae (Macedo et al., 1977). Esses dados são antigos, obtidos em trabalhos conduzidos em condições diferentes das encontradas atualmente.

Nos últimos cinco anos, desde o surgimento da praga a relação de trabalhos publicados apenas em congressos e simpósios de entomologia e controle biológico sobre a cigarrinha aumentou significativamente. Essa "busca" por informações visa preencher a "lacuna" de pesquisa $e$ informações sobre a praga dos últimos 20 anos, período em que o sistema de manejo da cultura de cana-de-açúcar não favorecia o desenvolvimento da $M$. fimbriolata. 
Muitos trabalhos têm sido feitos com o objetivo de avaliar a utilização de M. anisopliae como método de controle, principalmente em áreas em que o fungo ocorre naturalmente. Porém, nem sempre o isolado encontrado na área é o mais indicado para a produção e aplicação massal. Outro problema encontrado é a dificuldade em avaliar a infecção do fungo a campo. Encontram-se, comumente, cigarrinhas infectadas por M. anisopliae, mas saber se sua presença é devido à aplicação do fungo ou é uma ocorrência natural é muito difícil e sua correta identificação e caracterização se tornam importantes em um programa de controle. Dessa forma é necessário encontrar um método eficiente para avaliar o desempenho do isolado aplicado.

Atualmente, estão sendo utilizadas técnicas genéticas moleculares visando resolver problemas taxonômicos e de variação genética para vários fungos entomopatogênicos, além de auxiliar no controle de qualidade de micoinseticidas, proteção de patente, monitoramento ambiental $e$ persistência do produto (Hegedus \& Khachatourians, 1996a).

Dessa maneira, os objetivos do presente trabalho foram selecionar e caracterizar morfológica e geneticamente, por meio de técnicas de análise de DNA (RAPD), isolados de M. anisopliae relacionados ao agroecossitema da cana, visando correlacionar aspectos de patogenicidade, morfológicos e genéticos do fungo, para auxiliar a avaliação do potencial do microrganismo a campo. 


\section{REVISÃO DE LITERATURA}

\subsection{Mahanarva fimbriolata}

A cigarrinha-da-raiz, Mahanarva fimbriolata Stal (Hemiptera: Cercopidae), foi descrita pela primeira vez por Stal (1854) no gênero Monecphora Amyot \& Serville, 1843. Desde sua descrição, foi incluída em outros gêneros até que em 1968, Fennah revisou os cercopídeos neotropicais e, pelas características da genitália dos machos redefiniu vários gêneros e criou outros novos, transferindo a espécie em questão para o gênero Mahanarva Distant, 1909 (Fennah, 1968).

As primeiras referências sobre cercopídeos atacando cana-deaçúcar no Brasil datam de 1918, quando um surto de cigarrinhas foi controlado por um fungo. M. fimbriolata foi descrita pela primeira vez atacando cana-de-açúcar em 1919 e 1920 (Guagliumi, 1968).

M. fimbriolata apresenta como característica na cultura atacada, a presença de abundante espuma branca na base das touceiras, envolvendo as ninfas e protegendo-as de inimigos naturais e da dessecação durante todo o seu desenvolvimento (Cottas et al., 1983). O período de maior atividade destas cigarrinhas ocorre nos meses quentes e úmidos, pois a umidade é um 
fator limitante ao seu desenvolvimento, assim, durante os meses secos e frios, as ninfas e adultos desaparecem quase que totalmente, restando nas reentrâncias do solo e na base das touceiras, grande quantidade de ovos em diapausa, que eclodirão com a vinda do período chuvoso, dando início às outras gerações (Azzi \& Dodson, 1971; Botelho et al., 1976).

Os adultos são de hábito crepuscular-noturno, ficando escondidos dentro das olhaduras ou no enviés das folhas durante o dia (Guagliumi, 1973; Gallo et al., 2002). O macho adulto de M. fimbriolata tem cerca de $13 \mathrm{~mm}$ de comprimento e $6,5 \mathrm{~mm}$ de largura, coloração avermelhada com as tégminas orladas de preto e com uma faixa longitudinal da mesma cor. Nas fêmeas as tégminas são mais escuras e de coloração marrom-avermelhada. As posturas são efetuadas em bainhas secas na região do colo da planta, próximo ao solo, ou sobre o solo nas proximidades dos colmos da cana, em número de 50 a 70 ovos/fêmea. Ao sair do ovo a ninfa mede apenas $1 \mathrm{~mm}$ e, após quatro ecdises, atinge cerca de 10mm, quando sofre a última ecdise (Azzi \& Dodson, 1971; Mendonça et al., 1996). Com ciclo de duração média de 20 dias para a fase de ovo, 20 dias para a fase de ninfa e 20 dias para o adulto, podem ocorrer três a quatro gerações durante os períodos chuvosos que, na região Sudeste do Brasil, é de setembro/outubro a fevereiro/março (Gallo et al., 2002; Macedo \& Macedo, 2004). Os ovos da última geração entram em diapausa e as ninfas eclodem quando as condições climáticas se tornam favoráveis, porém, observa-se que essa praga não ataca necessariamente nas mesmas áreas, em anos consecutivos. Ocorre uma migração das altas infestações de um local (fazenda ou bloco) para outro. 
As ninfas, ao se alimentarem, ocasionam uma "desordem fisiológica" na planta em decorrência de suas picadas que, ao atingirem os vasos lenhosos da raiz, o deterioram, impedindo ou dificultando o fluxo de água e de nutrientes constituindo, assim, a fase mais prejudicial da praga, necrosando as raízes e permitindo a entrada de fungos patogênicos à planta. A morte de raízes ocasiona desequilíbrios na fisiologia da planta, provocando desidratação do floema e do xilema, "chochamento" e afinamento do colmo, levando posteriormente, ao aparecimento de rachaduras e rugas na superfície externa deste. Os adultos também podem se alimentar no sistema radicular além da seiva das folhas, injetando toxinas que produzem manchas nas folhas, ocasionando a seca das mesmas, reduzindo o processo fotossintético e a circulação da seiva do limbo foliar, ocasionando diminuição no conteúdo de sacarose do colmo e retardando a maturação (El-Kadi, 1977: Macedo \& Macedo, 2004).

Os danos decorrentes podem ser classificados em diretos e indiretos. Os danos diretos se caracterizam pela morte, encurtamento, rachadura, brotações laterais e murchamento de colmos e redução na produtividade (tonelada de cana/ha) causada por morte precoce de perfilhos. Já os indiretos, pela redução da quantidade e qualidade do açúcar recuperável causada por aumento no teor de fibra, aumento de impurezas (trash), redução da porcentagem de Pol do caldo da cana (PCC), redução na pureza do caldo e aumento de contaminantes no caldo (Dinardo-Miranda et al., 2004a; Macedo \& Macedo, 2004).

Atualmente, conforme observado por Dinardo-Miranda et al. (2001), grande parte das variedades cultivadas é susceptível à praga, 
causando reduções de produtividade em decorrência de seu ataque. Assim, diversos ensaios têm sido conduzidos com o objetivo de avaliar a eficiência de inseticidas, do fungo M. anisopliae e do afastamento da palha da linha de cana-de-açúcar, para incluir esses métodos em um programa de manejo da praga (Dinardo-Miranda et al., 2004a).

Dinardo-Miranda et al. (1999) avaliando os danos causados por M. fimbriolata a diferentes genótipos de cana-de-açúcar verificaram queda média de produtividade de $42,2 \%$ e $44,8 \%$ para primeiro e segundo cortes de cana, respectivamente. Além do genótipo, os autores observaram que a época de colheita influenciou essa queda de produtividade. Áreas colhidas mais tardiamente tiveram maiores perdas em produtividade.

As áreas com maiores infestações possuem aspecto de canavial queimado, com as folhas superiores apresentando estrias amareladas, pardas ou necrosadas, além de grande quantidade de espuma ao redor das touceiras (Azzi \& Dodson, 1971).

Há diversos fatores que influenciam a época e a duração da ocorrência da praga, constatando-se, de modo geral, que:

- Canaviais em solos argilosos e com alta capacidade de retenção de umidade estão sujeitos a maiores infestações, enquanto que os arenosos, com baixa capacidade de retenção de umidade (latossolos arenosos e areias quartzosas) estão livres de severos ataques;

- Canaviais colhidos no início da safra (maio/junho) estão sujeitos a infestações mais elevadas, precocemente (depois do aparecimento de condições favoráveis), do que aqueles colhidos tardiamente (setembro a novembro); 
- Canaviais atacados precocemente e que estão na fase inicial de desenvolvimento são os que sofrem as maiores perdas, especialmente pela morte e/ou menor desenvolvimento dos colmos.

- Canaviais que sofrem ataques severos mais tardiamente ou que estão mais desenvolvidos vegetativa e fisiologicamente (colmos bem desenvolvidos) sofrem perda em tonelagem, mas, principalmente, na qualidade.

Embora haja poucas informações sobre níveis de infestações e danos econômicos que variam conforme a variedade $e$ o estágio de desenvolvimento da lavoura, há indicações de que o nível de dano e o nível de controle estejam ao redor de 8-10 e 3-5 ninfas por metro linear de touceiras de cana, respectivamente.

\subsubsection{Controle de Mahanarva fimbriolata}

Para o manejo integrado desta cigarrinha, diversas medidas podem ser recomendadas como: método físico, método cultural, método químico e método biológico.

O método físico pode ser feito pelo afastamento mecânico da palha da linha de cana ou a retirada da palha da área, que proporciona menor infestação quando comparadas à situação normal da palha, mas não evitam totalmente a ocorrência da praga (Dinardo-Miranda, 2002); ou o controle com fogo em áreas muito infestadas, para diminuir o foco da praga, uma vez 
que dessa forma destrói-se suas formas biológicas, inclusive os ovos em diapausa (Balbo Jr. \& Mossim, 1999).

O método cultural consiste no emprego de variedades resistentes.

Esse método é praticamente inviável porque, embora tenham sido observadas variações significativas nos níveis de infestação e de danos, conforme as variedades, na prática todas as variedades cultivadas comercialmente sofrem ataques e estão sujeitas a perdas expressivas quando a pressão de população na área é elevada. O que pode e que deve ser efetuado é a redução da participação de variedades altamente suscetíveis no contingente de variedades plantadas.

O método químico com a aplicação de produtos de ação sistêmica (como Aldicarb, Carbofuran e Thiamethoxam), tem se mostrado, até o momento, uma alternativa bastante eficiente, porém, quanto ao aspecto econômico, é indispensável agregar ao conhecimento dos produtos o número e a época de aplicação mais indicada. As pesquisas recentes têm indicado que os melhores resultados, em termos de controle e ganho de produtividade, têm sido obtidos com uma única aplicação do produto nos intervalos entre a $1^{a}$ e a $2^{a}$ geração da praga, assim que se atingir o nível de controle. A estratégia mais prática para o monitoramento da população da praga é a colocação de armadilhas atrativas nas áreas de colheita de cana "crua", para a captura de adultos da primeira geração. Coletados os primeiros adultos, iniciam-se os levantamentos de populações médias de ninfas por metro linear, parâmetro que vai definir quando se atingiu o nível de controle.

Apesar de ser uma alternativa eficiente o controle químico apresenta algumas desvantagens como a ressurgência e aparecimento de 
novas pragas; surtos de pragas secundárias; deriva; resistência de pragas (Gallo et al., 2002); o elevado custo de aplicação e principalmente o desequilíbrio biológico que pode causar no ecossistema da cultura, eliminando inimigos naturais presentes na área que estariam contribuindo para o controle da praga como, por exemplo, Salpingogaster nigra (Diptera: Syrphidae), cujas larvas se alimentam de ninfas de cigarrinha.

Por fim, o método biológico, principalmente o microbiano, com o fungo M. anisopliae, que é de ocorrência natural em muitas áreas e vem sendo produzido em laboratório e aplicado a campo com resultados promissores em algumas regiões. Deve-se lembrar que o objetivo do controle microbiano, como em qualquer programa de controle biológico, não deve ser a total eliminação da população da praga, pois, sendo ela um componente do agroecossistema, sua presença, em níveis abaixo do nível de dano econômico, pode ser benéfica para a manutenção de outras pragas potenciais abaixo do nível de dano econômico, dos predadores, parasitóides e patógenos já presentes na área (Sosa-Gómez et al., 1998).

A utilização dessa técnica para o controle de M. fimbriolata tem sido testada e utilizada há muito tempo e é extremamente interessante por razões ambientais e econômicas. Freire et al. (1968) fizeram levantamentos sobre os principais inimigos naturais de cigarrinhas da cana-de-açúcar e constataram a importância e potencial do fungo M. anisopliae. Macedo et al. (1977) avaliaram o fungo M. anisopliae para o controle de cigarrinha-da-raiz como alternativa para o controle químico e por ser um agente de controle constatado como sendo de ocorrência natural. 
As doses utilizadas comercialmente variam muito (de 1 a $10 \mathrm{~kg} / \mathrm{ha}$ de arroz esporulado), bem como o modo de aplicação. Alguns produtores lavam os grãos de arroz em água e aplicam a calda resultante (conídios do fungo + água), enquanto outros distribuem diretamente os grãos de arroz infestados, geralmente por avião (Dinardo-Miranda et al., 2004b).

Dinardo-Miranda et al. (2004b) avaliaram a eficiência de isolados de M. anisopliae no controle da cigarrinha-da-raiz em condições de campo, em três municípios do estado de São Paulo, e observaram redução de população de até $91,2 \%$ quando foram feitas duas aplicações, utilizando-se em cada uma a dose de $1 \mathrm{~kg} / \mathrm{ha}$ de arroz esporulado (aproximadamente $9 \times$ $10^{8}$ conídios/g de arroz).

\subsection{Metarhizium anisopliae}

Metarhizium é um dos gêneros mais conhecidos de fungos entomopatogênicos. É um Deuteromiceto pertencente à ordem Moniliales, família Moniliaceae. Co-evolui em associação com insetos e foi identificado pela primeira vez por Metschnikoff, em 1879, em um coleóptero, Anisoplia austríaca, (Coleoptera: Scarabaeidae) como Entomophtora anisopliae e que se caracteriza por atacar um grande número de espécies de insetos (Zimmermann, 1993). Em 1883, Sorokin o classificou como Metarhizium anisopliae e desde então a utilização e ação deste patógeno vêm sendo estudada sobre muitas espécies de insetos. Atualmente, é utilizado para controle de pragas em muitos países como EUA, Brasil, Austrália entre outros. Segundo Zimmermann (1993), quatro grupos de insetos-praga tem 
sido controlados com M. anisopliae sendo eles: cupins, gafanhotos, cigarrinhas e besouros (incluindo sua fase larval). A maioria destas pragas está extensamente distribuída e tem grande importância econômica nas culturas em que ataca.

A classificação atual de Metarhizium é baseada em caracteres morfológicos e foi revisadas por Tulloch (1976), que aceitou apenas $M$. flavoviridae e M. anisopliae, com essa segunda espécie sendo subdividida em var. anisopliae ou var. majus, dependendo do tamanho do conídio (Zimmermann, 1993; Driver et al., 2000).

Os insetos colonizados por Metarhizium tornam-se duros e cobertos por uma camada pulverulenta de conídios. A doença é conhecida como muscardine verde, pois no final da conidiogênese os cadáveres apresentam tons de verde que varia do claro ao escuro, acinzentados ou ainda esbranquiçados com pontos verdes. Os conídios são normalmente uninucleados, hialinos ou fracamente coloridos e se formam sobre conidióforos simples que, justapostos, resultam em uma massa regular sobre o inseto. Seu ciclo de vida é simples: a unidade infecciosa é assexual, conidiósporo haplóide, formado em cadeias, em fiálides que podem ou não estarem entumecidas. O ciclo parassexual é a principal alternativa de $M$. anisopliae para haver troca de material genético, como foi demonstrado por Wang et al. (2002), que observaram também que se o fungo for mantido por muito tempo apenas em meio de cultura artificial pode perder sua virulência. Os conídios germinam na cutícula de um inseto suscetível, produz um tubo germinativo que penetra na cavidade do corpo do inseto onde o fungo prolifera como hifas, matando o hospedeiro. Depois de morte, se as 
condições forem favoráveis, o fungo cresce e esporula servindo de fonte de inóculo para outros indivíduos. Não é conhecida fase telemorfa para Metarhizium, exceto a de M. taii que é Cordyceps taii (Alves, 1998; Driver et al., 2000).

A mais comum das espécies é $M$. anisopliae que é encontrada atacando muitas espécies de insetos sendo que, alguns isolados, possuem considerável especialização em relação ao hospedeiro. Muitas diferenças na patogenicidade indicam que naturalmente ocorre variação genética. Outros fatores relacionados a patogenicidade incluem a dimensão dos conídios, taxa de crescimento do fungo e atividade enzimática (St. Leger et al., 1992).

$O$ primeiro trabalho utilizando o fungo $M$. anisopliae para controle de pragas data de 1879, pelo russo Ilya Metchnikoff, que aplicou o fungo em larvas de um curculionídeo, praga de beterraba (Alves, 1998).

Acredita-se que a espécie $M$. anisopliae ocorra naturalmente sobre mais de 300 espécies de insetos das diferentes ordens, incluindo pragas importantes. Aproveitando-se da variabilidade natural desse fungo, diversos trabalhos foram realizados com o objetivo de selecionar isolados para o controle de pragas, em diferentes regiões do Brasil, como: cupim de montículo em pastagens, pragas de grãos armazenados e larvas de escarabeídeos que atacam a cana-de-açúcar, cigarrinha das folhas (Mahanarva posticata) em cana-de-açúcar, cigarrinhas das pastagens (Deois flavopicta e Zulia entreriana) (Fernandes \& Alves, 1991; Milner, 1992; Moino Júnior, 1993; Almeida, 1994; Tigano-Milani et al., 1995a). Estudos envolvendo sua caracterização fisiológica e molecular vêm sendo realizados 
para se avaliar melhor as características entomopatogênicas por ele exibidas (Braga, 1997).

O ciclo das relações fungo-hospedeiro depende de condições ambientais (temperatura, umidade, luz, radiação ultravioleta), condições nutricionais e suscetibilidade do hospedeiro. A maioria dos fungos entomopatogênicos requer, pelo menos, $95 \%$ de umidade relativa na superfície do inseto para a germinação, extensão do tubo germinativo e infecção (Hallworth \& Magan, 1999).

A entomopatogenicidade do fungo, que é sua capacidade de produzir doença em insetos, depende de uma sequiência de eventos mecânicos e bioquímicos que ocorrem de forma sincronizada pela deposição do conídio sobre a cutícula do inseto, seguida pela germinação do conídio, penetração através da cutícula dada por ação mecânico-enzimática, invasão, colonização do corpo do inseto e produção de toxinas, exteriorização das estruturas fúngicas e produção de conídios sobre a carcaça do hospedeiro (St. Leger et al., 1991).

Mais detalhadamente, este ciclo apresenta as seguintes fases: adesão, germinação, formação de apressórios, formação de grampo de penetração, penetração, colonização, reprodução e disseminação do patógeno. Os eventos de infecção de M. anisopliae em seu hospedeiro são adesão, com a presença do muco que envolve os conídios possuindo altos níveis de aminopeptidases, que podem criar condições favoráveis para a atuação de enzimas extracelulares; germinação, que ocorre em condições favoráveis de umidade, temperatura, pH, oxigênio e nutrição; a formação de um apressório (extremidade dilatada da hifa com alta atividade secretora 
enzimática, que permite a penetração da epicutícula), penetração da prócutícula, que envolve processo físico (pressão da hifa terminal que rompe as áreas membranosas ou esclerosadas) e químico (elaboração de enzimas: proteases, lípases e quitinases) e formação de células com abundância de nutrientes armazenados (clamidósporo) que parece manter a viabilidade do fungo no corpo do hospedeiro por longos períodos até a esporulação superficial (Alves, 1998).

Os fungos entomopatogênicos penetram seus hospedeiros diretamente através da cutícula, que é uma barreira natural para muitos microrganismos. Antes mesmo de o conídio penetrar a cutícula do hospedeiro existem propriedades não específicas, por exemplo, a hidrofobicidade, e antígenos específicos que permitem a adesão do conídio. Essa infecção é possível pela combinação de enzimas digestivas e micotoxinas que o fungo entomopatogênico produz e libera (Chen et al., 1999; Jeffs et al., 1999). Conseqüentemente eles têm alto potencial como agentes de controle de insetos-praga. Estes fungos produzem uma série de enzimas proteolíticas e quitinolíticas que facilitam a penetração na cutícula do inseto, que é a maior barreira física para a infecção (Joshi et al., 1997). Tanto as proteases quanto as quitinases estão envolvidas na patogenicidade dos fungos entomopatogênicos aos seus hospedeiros (St. Leger et al., 1993). Isolados altamente patogênicos apresentam quantidade detectável de atividade extracelular de quitinase, lipase e protease que são muito ativas, de amplo espectro e necessárias para a penetração da epicutícula hidrofóbica e da cutícula de alto conteúdo protéico (Roberts et al., 1992). M. anisopliae possui duas enzimas quitinases distintas que são caracterizadas $e$ 
responsáveis pela regulação e indução da degradação da quitina (Kang et al., 1999). St. Leger et al. (1993) citaram que a regulação da produção de quitinase pelos fungos sugere que o sistema é similar ao realizado pelos saprófitas, mas a complexidade dos tipos de quitinases ainda não foram estudadas.

Os fungos entomopatogênicos, que invadem o hospedeiro pela cutícula têm enzimas que degradam essa cutícula. Essas enzimas além de favorecer a penetração do fungo, convertem o tecido do inseto em nutrientes para seu crescimento (Roberts et al., 1992).

M. anisopliae utiliza uma combinação de enzimas e força mecânica para penetrar a cutícula de seu hospedeiro e ter acesso a hemolinfa, rica em nutrientes. Uma das mais importantes enzimas, a quimoelastase, produzida pelo M. anisopliae, é chamada de $\operatorname{Pr} 1$. No momento da formação do apressório, $80 \%$ da síntese de proteína do M. anisopliae é convertida em síntese de Pr1. Isso sugere que a enzima Pr1 é um fator de virulência desse fungo. Além disso, fungos entomopatogênicos usualmente produzem metabólitos secundários tóxicos ou antibióticos $e$, as toxinas secretadas no meio pelo fungo podem atuar como antimicrobial ou agente anti-imune, eliminando assim a competição por nutrientes ou facilitando o estabelecimento do patógeno (Roberts et al., 1992; Wang et al., 2002).

M. anisopliae também produz toxinas do grupo dos ciclopeptídeos, as destruxinas, que desempenham papel importante na patogênese do fungo, apresentando várias propriedades biológicas, em particular, atividades inseticida e fungicida (Roberts, 1969; Potterat et al., 2000; Hsiao \& Ko, 2001). 
Em 1961, Kodaira isolou duas destruxinas, $A$ e $B$, de culturas filtradas de M. anisopliae (Suzuki et al., 1970). Suzuki et al. (1971) isolaram mais três destruxinas, $C, D$ e desmetildestruxina $B$; os autores verificaram também que a produção dessas toxinas afeta e age inclusive na hemolinfa do inseto.

O grande interesse nas destruxinas deve-se ao fato delas estarem envolvidas na virulência de fungos entomopatogênicos e com potencial para uso de controle de pragas (Pedras et al., 2002). Essas micotoxinas são as únicas detectadas no corpo dos insetos infectados inclusive em estágios avançados da infecção, causando mortalidade. Mais de vinte diferentes destruxinas já foram isoladas e quinze destas foram originalmente isoladas de M. anisopliae (Loutelier et al., 1996; Chen et al., 1999).

\subsection{RAPD (Random Amplified Polymorphic DNA)}

Antes do advento de descoberta de tecnologia molecular, a classificação de fungos entomopatogênicos baseava-se apenas em características bioquímicas e morfológicas. Estas características incluíam reprodução, morfologia do conídio e da colônia, enzimas hidrolíticas, isoenzimas entre outras. Enquanto estes métodos tiveram êxito determinando os espectros de espécies dentro do gênero, estes mesmos estudos revelaram um grau alto de variação entre isolados obtidos de diferentes países e diversos hospedeiros (Tigano-Milani et al., 1995b; 
Hegedus \& Khachatourians, 1996b; Driver et al., 2000; Destéfano et al., 2004).

Muitos grupos de pesquisa, trabalhando com Metarhizium têm se esforçado para estabelecerem um método conveniente para que diferenças inter e intra-específicas possam ser facilmente detectadas (Mavridou \& Typas, 1998).

Como o material genético é uma característica constante, métodos baseados no DNA oferecem a possibilidade de distinção de linhagens estritamente relacionadas. Técnicas moleculares como PCR (Polymerase Chain Reaction), RFLP (Restriction Fragment Length Polymorphism) e RAPD (Random Amplified Polymorphic DNA) vêm sendo aplicadas na avaliação do polimorfismo das diferentes espécies de fungos, constituindo-se em poderosas ferramentas para o diagnóstico preciso destes microrganismos nos vários níveis taxonômicos (Cobb \& Clarkson, 1993; Leal et al., 1994a; Fungaro et al., 1996; Mavridou \& Typas, 1998; Pantou et al., 2003).

PCR é uma técnica que envolve a síntese enzimática "in vitro" de milhões de cópias de um segmento específico de DNA na presença da enzima DNA polimerase. A reação de $P C R$ se baseia no anelamento e extensão enzimática de um par de oligonucleotídeos utilizados como "primers" (iniciadores) que delimitam a sequiência de DNA de fita dupla alvo na amplificação (Ferreira \& Grattapaglia, 1995).

Uma das variações da PCR, o RAPD, é baseada na observação de que um "primer" de DNA simples, com uma sequiência arbitrária de nucleotídeos, pode amplificar a seqüência de DNA genômico sem a 
necessidade de prévio conhecimento da sequiência de bases do DNA alvo e essa é a maior vantagem desta técnica (Baumann et al., 2003). Evidências experimentais indicam que diferenças de apenas um par de bases são suficientes para causar a não complementaridade do "primer" com sítio de iniciação e assim impedir a amplificação de um segmento. Assim, o polimorfismo genético detectado pelo RAPD tem natureza binária, ou seja, o segmento amplificado (banda no gel) está presente ou ausente (Ferreira \& Grattapaglia, 1995; Baumann et al., 2003). Essa técnica, em particular, tem sido amplamente utilizada para caracterização molecular de espécies de plantas, bactérias e fungos, incluindo os entomopatogênicos (Cobb \& Clarkson, 1993; Hegedus \& Khachatourians, 1996a). É também uma excelente ferramenta para identificação de espécies ou isolados, e estimativa da variabilidade genética entre isolados e construção de dendrogramas (Oborník et al., 2000).

Análise de RAPD tem sido utilizada para separar variedades dos fungos entomopatogênicos Hirsutella longicolla e M. anisopliae (Hegedus \& Khachatourians, 1993), além de Beauveria bassiana, M. flavoviride, Paecilomyces fumosoroseus entre outros (Castrillo \& Brooks, 1998). Por falta de marcadores morfológicos capazes de distinguir subespécies de $M$. anisopliae, RAPD's estão sendo explorados com alto potencial para verificar a variação genética nesses fungos isolados de diferentes regiões $e$ hospedeiros (Welsh \& McClelland, 1990; Fegan et al., 1993; Bidochka et al., 1994; Fungaro et al., 1996, Pantou et al., 2003). Em alguns casos, essa técnica pode ser correlacionada com a patogenicidade, a distribuição geográfica e a preferência ao hospedeiro (Hegedus \& Khachatourians, 1993). 
Estes estudos revelaram alto grau de variabilidade intraespecífica dentro de espécies determinadas morfologicamente e entre isolados provenientes da mesma área geográfica na Austrália (Bidochka et al., 1994; Fegan et al., 1993).

Oborník et al. (2000), estudando a variabilidade genética de $P$. fumosoroseus, P. farinosus, P. lilacinus e Verticillium lecanii, concluíram que marcadores de RAPD podem ser utilizados com sucesso para reconstruir a relação intraespecífica, interespecífica e a filogenia de fungos entomopatogênicos hifomicetos tanto quanto avaliar sua variabilidade genética.

Berretta et al. (1998) examinaram a diversidade genética de 18 isolados de B. bassiana com a técnica de RAPD e verificaram alta variabilidade entre os genótipos e não encontraram correlação entre os isolados quanto a sua origem geográfica ou hospedeiro.

Antes de utilizar isolados específicos, como agentes de controle biológico, é necessário demonstrar sua efetividade. Isto requer a determinação precisa de quais isolados estão controlando o inseto-praga em condições de campo (Tigano-Milani et al., 1995a, b).

A caracterização por RAPD pode ser útil ainda quando novos isolados são introduzidos dentro de um ecossistema para o controle biológico de determinada praga. Isso assegura a detecção do patógeno introduzido versus o nativo, para se saber qual está, efetivamente, controlando a praga (Devi et al., 2001). Além disso, a técnica pode ser introduzida como controle de rotina para verificar a estabilidade genética do fungo em produção massal (Berretta et al., 1998). 
Com o uso de M. anisopliae e outros fungos entomopatogênicos como bioinseticida, a correta identificação destes fungos se tornou muito importante, mas, apenas poucos deles têm sido intensivamente investigados e examinados em nível molecular. O monitoramento e o controle de qualidade dos micoinseticidas deve ser realizado e o produto (fungo) deve ser identificado corretamente e distinguível de outros existentes no campo que possam co-existir nos locais de aplicação, não somente para proteção de patentes, também para assegurar a estabilidade do isolado e avaliar sua utilização em condições de campo e seu possível impacto ao meio ambiente (Fegan et al., 1993; Leal-Bertioli et al., 2000; Destéfano et al., 2004). Isolados 'selvagens' de M. anisopliae exibem significativa variabilidade genética. Leal-Bertioli et al. (2000) reportaram a instabilidade dos fenótipos de M. anisopliae sendo manifestada com variação na morfologia das colônias, incluindo exudação de metabólitos e a produção de protease e sua virulência. Vários estudos aplicam técnicas moleculares para a caracterização de Metarhizium (Inglis et al., 2000). A extensa e natural variação genética que ocorre em $M$. anisopliae tem sido avaliada por análise de perfil de isoenzimas (Rakotonirainy et al., 1994), cromatografia, taxa de crescimento, virulência e produção extracelular de enzimas $e$, todas essas técnicas, detectaram um elevado grau de variabilidade intraespecífica (Fungaro et al., 1996). A maior desvantagem da utilização de análise de perfil de isoenzimas é que elas podem variar durante o crescimento do fungo com isso, grupos monofiléticos gerados pelo dendrograma de isoenzimas não correspondem a espécies morfologicamente diferentes (St. Leger et al., 1992). Em contrapartida, o material genético é um aspecto constante, e 
métodos baseados em análise de DNA podem oferecer maior possibilidade de distinção entre isolados de uma mesma espécie que crescem em diferentes condições (Leal et al., 1994a). Mais recentemente, a introdução de técnicas de PCR (Polymerase Chain Reaction) permitiu detectar polimorfismo dentro do DNA.

Driver et al. (2000) utilizaram análise de DNA ribossomal para uma revisão taxonômica do gênero Metarhizium. Esse estudo revelou as limitações da caracterização morfológica na distinção de espécies de Metahizium. Os autores mostraram que a morfologia da fiálide de um determinado isolado pode variar no mesmo meio de cultura, tanto quanto em substratos diferentes. Além disso, eles concluíram que a morfologia do conídio foi o único caráter morfológico potencialmente útil. Os grupos fenéticos formados pela técnica de RAPD foram separados em grupos de ITS (Internal Transcribed Spacer) com sequiência idêntica. Isolados que tiveram perfis de RAPD idênticos, ou exibiram menor polimorfismo com alguns "primers" sempre pertenceram também ao mesmo grupo de ITS. Esses resultados confirmam que há maior variabilidade no padrão de bandas de RAPD em M. anisopliae var. anisopliae, como mostraram Bidochka et al. (1993) e Fegan et al. (1993).

Utilizando PCR e RAPD, Bidochka et al. (1993) e Fegan et al. (1993) concluíram que a espécie M. anisopliae contém espécies crípticas que são aquelas que apresentam o mesmo fenótipo, ou seja, são indistinguíveis morfologicamente, no entanto em outros caracteres são completamente diferentes e possuem a mesma distribuição geográfica. Fegan et al. (1993) e Fungaro et al. (1996) demonstraram que, em alguns casos, grupos formados 
pelo RAPD podem ser correlacionados com o hospedeiro e a origem geográfica.

O conceito de espécie está sendo aceito com uma definição mais flexível $e$ isso é particularmente relevante para resolver problemas de taxonomia e genética de fungos. A maior parte das divisões taxonômicas são implícitas e baseadas no conceito biológico de espécies de que são consideradas espécies distintas as que são reprodutivamente isoladas. $\mathrm{Na}$ prática, observam-se facilmente caracteres morfológicos sendo utilizados para separação de espécies. Porém, muitos estudos não são concordantes sobre a separação das espécies e subespécies (Driver et al., 2000).

O conceito biológico de espécies que delimita populações em "taxa" não é diretamente aplicado para M. anisopliae. Todo o ciclo parassexual dentro do gênero e seu potencial de troca genética tem sido demonstrado. Utilizando análise de isoenzimas St. Leger et al. (1992) demonstrou considerável relação interisolados e a existência de estruturas de população-clone dentro de espécies de Metarhizium, que podem ter surgido como o resultado de incompatibilidade de heterocárion ou outro mecanismo resultante do isolamento genético. Observações similares foram notadas em análises de RAPD. O maior problema com a taxonomia é a dificuldade de fornecer caracteres facilmente identificáveis. Enquanto algumas classes são facilmente identificadas, outras são possíveis apenas por métodos moleculares (Driver et al., 2000). 


\section{MATERIAL E MÉTODOS}

\subsection{Patogenicidade de isolados de Metarhizium anisopliae a Mahanarva fimbriolata}

O experimento foi conduzido no Laboratório de Patologia e Controle Microbiano de Insetos do Setor de Entomologia da ESALQ-USP e consistiu em avaliar a patogenicidade de 20 isolados de $M$. anisopliae para $M$. fimbriolata. $O$ delineamento foi inteiramente casualizado com 30 insetos por tratamento, divididos em 10 repetições (3 ninfas/repetição). Dos 20 isolados de M. anisopliae testados, onze encontram-se armazenados em freezer $\left(-12^{\circ} \mathrm{C}\right)$ na forma de conídios puros, sob óleo mineral e/ou liofilizados no Banco de Patógenos do referido laboratório. Os outros nove isolados foram fornecidos pelo Laboratório de Controle Biológico do Instituto Biológico de Campinas (IBCB). Dezoito isolados testados foram obtidos de cigarrinhas ( $M$. fimbriolata e M. posticata), um de Diatraea saccharalis (ESALQ 935), e o isolado padrão (ESALQ 1037) foi obtido de Solenopsis sp. (Tabela 1). 
Tabela 1. Isolados de Metarhizium anisopliae testados para o controle de Mahanarva fimbriolata

\begin{tabular}{ccc}
\hline Isolado & Hospedeiro & Origem \\
\hline ESALQ 319 & M. posticata & Goânia - PE \\
ESALQ 935 & Diatraea saccharalis & Itabuna - BA \\
ESALQ 1037 (padrão) & Solenopsis sp. & Porto Alegre - RS \\
ESALQ 1204 & M. fimbriolata & Piracicaba - SP \\
ESALQ 1286 & M. fimbriolata & Valparaíso-SP \\
ESALQ 1294 & Cercopidae & Guaira - SP \\
ESALQ 1301 & M. fimbriolata & Iturama - MG \\
ESALQ E9 & M. posticata & Boca da Mata - AL \\
ESALQ PL26 & M. posticata & Nordeste \\
ESALQ PL43 & M. posticita & Fleixeira del Estado- AL \\
ESALQ PL49 & M. posticata & Nordeste \\
IBCB - 333 & M. fimbriolata & Valparaíso - SP \\
IBCB - 334 & M. fimbriolata & Novo Horizonte - SP \\
IBCB - 345 & M. fimbriolata & Cosmópolis - SP \\
IBCB - 348 & M. fimbriolata & Sertãozinho - SP \\
IBCB - 353 & M. fimbriolata & Valparaíso - SP \\
IBCB - 374 & M. fimbriolata & Sertãozinho - SP \\
IBCB - 380 & M. fimbriolata & Água Branca - SP \\
IBCB - 384 & M. fimbriolata & Sertãozinho - SP \\
IBCB - 391 & M. fimbriolata & Tabapuã - SP \\
\hline
\end{tabular}




\subsubsection{Obtenção das ninfas de Mahanarva fimbriolata}

As ninfas de M. fimbriolata foram coletadas, com o auxílio de colheres, em área de cultivo comercial de cana-de-açúcar, onde se faz a colheita de "cana crua", sem nenhum tratamento para o controle da praga (Usina São João, localizada no município de Araras - SP). Após a coleta, as ninfas foram acondicionadas em caixas plásticas $(37 \times 25 \times 11 \mathrm{~cm})$ contendo folhas de cana-de-açúcar e levadas ao laboratório onde, no dia seguinte, foram separadas por tamanho (de 5 a $7 \mathrm{~mm}$ de comprimento) em grupos de 30 , os quais foram pulverizados com os respectivos isolados do fungo.

\subsubsection{Produção dos isolados de Metarhizium anisopliae (Metsch.) Sorokin}

Conídios dos diferentes isolados foram transferidos para placas de Petri esterilizadas contendo meio de cultura completo $(M C)(0,36 \mathrm{~g}$ de fosfato de potássio; $1,05 \mathrm{~g}$ de fosfato de sódio; $0,6 \mathrm{~g}$ de sulfato de magnésio; $1,0 \mathrm{~g}$ de cloreto de potássio; $10 \mathrm{~g}$ de glucose; $1,58 \mathrm{~g}$ de nitrato de sódio; $5,0 \mathrm{~g}$ de extrato de levedura; $20 \mathrm{~g}$ de ágar; $1000 \mathrm{~mL}$ de água destilada) previamente autoclavado a $120^{\circ} \mathrm{C}$ por 20 minutos, e foram espalhados com o auxílio de alça de Drigalski. Após a inoculação, as placas foram mantidas em câmara climatizada do tipo B.O.D. (Biological Oxigen Demand) a $26 \pm 0,5^{\circ} \mathrm{C}$; $80 \pm 5 \%$ UR; 12 horas de fotofase durante um período de dez dias para crescimento e esporulação do fungo. 


\subsubsection{Preparo da suspensão de conídios}

Decorridos dez dias, os conídios foram retirados das placas, com o auxílio de uma espátula esterilizada, e transferidos para tubos de dieta contendo $10 \mathrm{~mL}$ de água destilada estéril mais espalhante adesivo a $0,01 \%$ (Tween $40^{\circledR}$ ). Foram feitas três diluições em série, sendo a terceira utilizada para a contagem dos conídios em câmara de Neubauer. Após esse procedimento, uma suspensão de concentração de $5 \times 10^{7}$ conídios viáveis por mililitro foi preparada, a partir da suspensão original, para ser pulverizada. Essa concentração foi utilizada em função de testes de patogenicidade realizados pelo Instituto Biológico de Campinas.

Cada isolado (tratamento) foi inoculado, por pulverização, em 30 ninfas de M. fimbriolata em uma placa de Petri de $14 \mathrm{~cm}$ de diâmetro. A pulverização foi realizada em Torre de Potter (Burkard Manufacturing Rickmansworth, Herts, Reino Unido) calibrada a 15 libras/pol ${ }^{2}$, utilizando-se dois mililitros da suspensão de conídios, correspondendo a $0,2 \mu \mathrm{L} / \mathrm{cm}^{2}$. $O$ tratamento Testemunha foi pulverizado com água destilada estéril mais espalhante adesivo a $0,01 \%$ (Tween $40^{\circledR}$ ).

Após a pulverização, os insetos foram transferidos para as raízes das mudas de cana-de-açúcar, perfazendo três ninfas/planta e dez plantas por tratamento. As mudas foram obtidas no Centro de Ciências Agrárias da Universidade Federal de São Carlos (CCA-UFSCar) em Araras-SP e vieram acondicionadas em copos plásticos os quais tiveram o fundo recortado para expor as raízes onde foram colocadas as ninfas já pulverizadas. Para 
individualizar as mudas cada copo, contendo uma muda, foi colocado sobre o fundo de uma placa de Petri ( $9 \mathrm{~cm}$ de diâmetro) e cada tratamento foi individualizado em bandejas plásticas (Figura 1). Estas mudas, molhadas diariamente com água destilada, foram mantidas em sala com fotofase de $12 \mathrm{~h}$ a $27 \pm 1^{\circ} \mathrm{C}$ durante todo o período de avaliação (Figura 1). As avaliações de mortalidade foram realizadas no quinto dia após a inoculação, sendo realizadas observações diárias, para coleta dos adultos que emergiam.
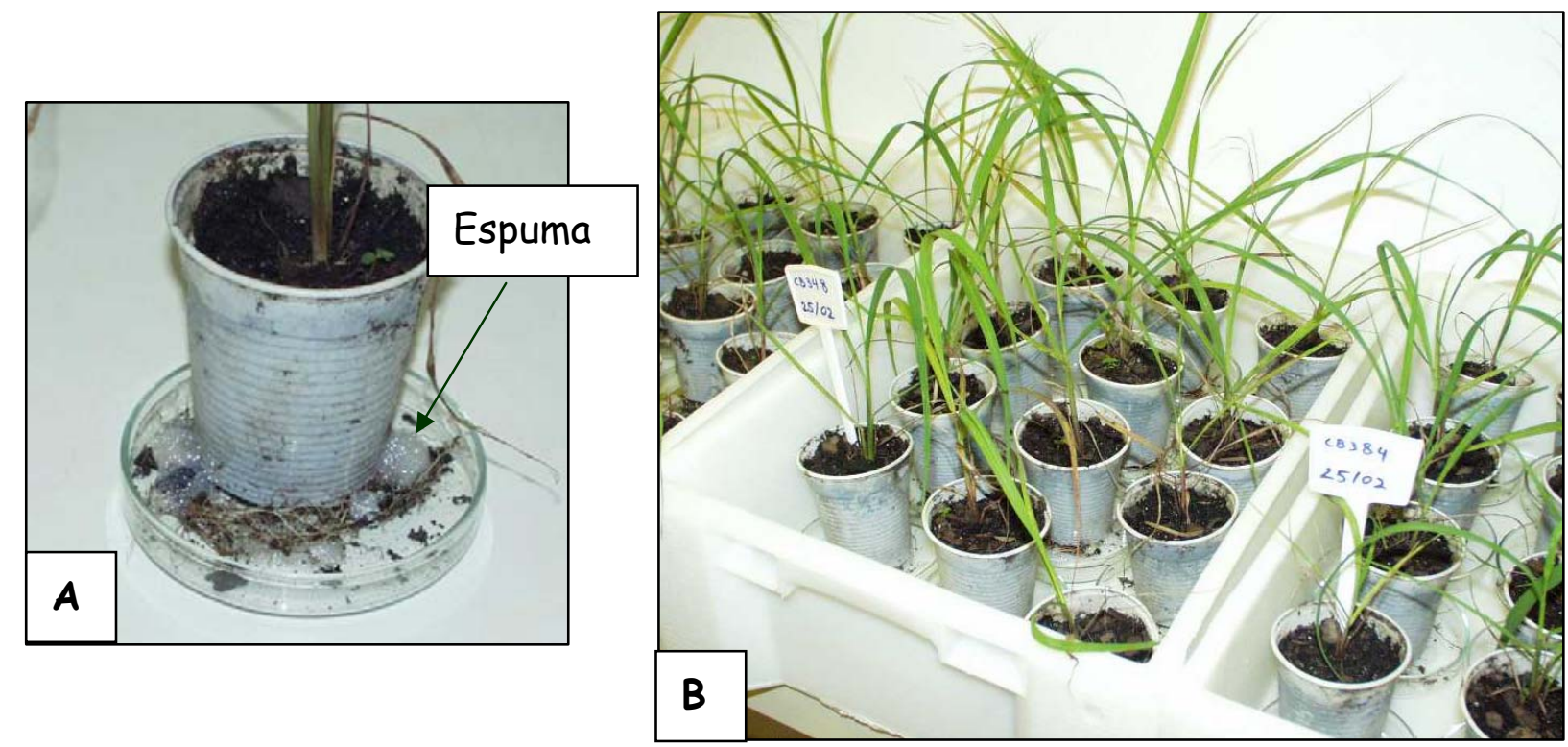

Figura 1 - A) Ninfas de Mahanarva fimbriolata apresentando espuma característica; B) Aspecto dos tratamento separados em bandejas

A seleção de isolados foi baseada na porcentagem de mortalidade de M. fimbriolata no período de avaliação, determinando-se assim a patogenicidade de cada isolado para o inseto. Os isolados selecionados foram aqueles que apresentaram maior mortalidade, corrigida pela da fórmula de 
Schneider-Orelli (1947) (Mortalidade corrigida $=[(\%$ de mortalidade no tratamento - \%mortalidade na testemunha)/(100 - \%mortalidade na testemunha)*100]), cinco dias após a inoculação.

\subsubsection{Produção dos isolados de Metarhizium anisopliae pelo processo da bandeja}

A produção inicial de conídios foi realizada em placas de Petri contendo meio de cultura completo (MC) (item 3.1.2). Os conídios foram inoculados nessas placas em câmara de fluxo laminar $e$, posteriormente, incubadas em câmara climatizada $\left(26 \pm 0,5^{\circ} \mathrm{C}, 80 \pm 5 \%\right.$ UR e fotofase de 12 horas), durante um período de sete dias para o crescimento e esporulação dos patógenos.

O sistema de produção utilizado foi o de bandeja desenvolvido por Alves \& Pereira (1989). Esse método consiste, basicamente, na utilização de sacos plásticos de polipropileno, onde foram colocados $300 \mathrm{~g}$ de arroz précozido e esterilizados em autoclave a $120^{\circ} \mathrm{C}$ por 20 minutos. Após o resfriamento, o arroz foi inoculado com uma suspensão das matrizes selecionadas. Depois de dois a três dias após a inoculação, foram selecionados os sacos de crescimento uniforme e sem contaminação e seu conteúdo transferido para bandejas plásticas. Essas foram mantidas em sala asséptica, sob temperatura de $27 \pm 1^{\circ} \mathrm{C}$ e 24 horas de fotofase, por 16 dias, para promover a esporulação do fungo. No sétimo dia, foi feito o cruzamento, por sobreposição, das bandejas para uma maior ventilação entre elas e secagem mais rápida do arroz com fungo (Figura 2). 


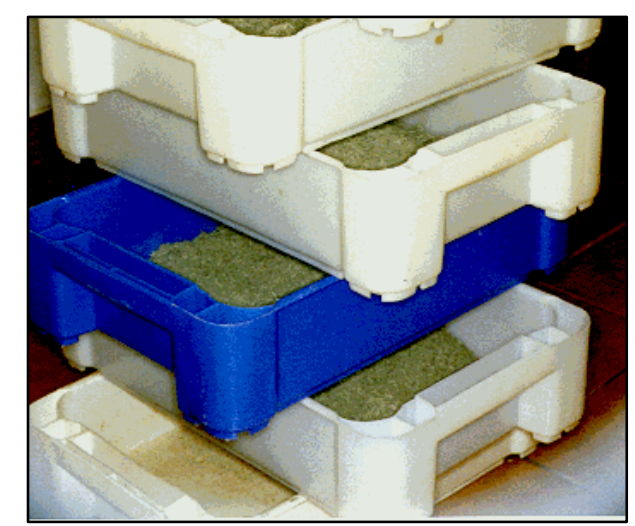

Figura 2 - Bandejas utilizadas para a produção do fungo

Foram realizadas observações diárias avaliando-se, visualmente, a presença ou ausência de eventuais contaminantes.

No décimo dia após a inoculação foram retiradas da superfície do substrato, a uma profundidade de $1,5 \mathrm{~cm}$, dez amostras de um grama, escolhidas ao acaso. As amostras foram colocadas em tubos de vidro contendo $10 \mathrm{~mL}$ de água destilada mais espalhante adesivo $0,01 \%$ (Tween $40^{\circledast}$ ). Os tubos foram agitados por um minuto em vórtex, e colocados em ultra-som por mais quatro minutos, para liberação dos conídios $e$ homogeneização da suspensão. Em seguida, as amostras foram diluídas em série e quantificadas com o auxílio da câmara de Neubauer. Dessa forma, foi possível determinar o número de conídios produzidos por grama para cada isolado selecionado. Os resultados da avaliação dos diferentes isolados foram submetidos à análise de variância e as médias comparadas pelo teste de Tukey a $5 \%$ de probabilidade. 


\subsection{Caracterização morfológica e genética dos isolados de Metarhizium anisopliae}

\subsubsection{Caracterização morfológica}

A caracterização morfológica baseou-se em caracteres morfológicos da colônia de cada isolado estudado. Foram avaliados: aspecto de crescimento da colônia, forma dos conidióforos e tamanho dos conídios.

Os isolados que se encontravam armazenados em freezer $\left(-12^{\circ} \mathrm{C}\right)$ na forma de conídios puros, no Laboratório de Patologia e Controle Microbiano de Insetos da ESALQ-USP, foram inoculados em placas de Petri contendo meio de cultura completo (MC) (item 3.1.2) e mantidos em câmara climatizada ( $26 \pm 1^{\circ} \mathrm{C}, 80 \pm 5 \%$ UR e fotofase de 12 horas) por oito dias, quando foram medidos os diâmetros das colônias (em milímetros) e as mesmas foram fotografadas.

Após o crescimento em meio de cultura completo $(M C)$, conídios dos isolados foram transferidos para outras placas também contendo o mesmo meio de cultura em três pontos eqüidistantes, dispostos em triângulo. Foram feitas duas placas por isolado, totalizando seis pontos por isolado. Após a inoculação as placas foram mantidas em câmara climatizada $\left(26 \pm 1^{\circ} \mathrm{Ce}\right.$ fotofase de 12 horas) por dois ou três dias, até o início de sua esporulação. Destas colônias foram feitas lâminas, com o corante azul lático, a fim de observar e fotografar os conidióforos do fungo. 
Para medir o tamanho dos conídios dos isolados de M. anisopliae, utilizou-se o meio de cultura B.D.A. (batata-dextrose-ágar) (15g de dextrosol; 0,5g de streptomicina; $200 \mathrm{~g}$ de batata; $20 \mathrm{~g}$ de ágar; $1000 \mathrm{~mL}$ de água destilada), onde os isolados foram inoculados em placas de Petri, em três pontos eqüidistantes e incubadas em câmara climatizada $\left(26 \pm 1^{\circ} \mathrm{C} e\right.$ fotofase de 12 horas) por oito dias para sua completa esporulação.

Decorrido esse tempo, foram feitas lâminas, com o corante azul lático, e os conídios foram observados em microscópio óptico e medidos com - auxílio do tambor OSM (ocular micrométrica, calibrada com micrômetro), acoplado ao microscópio. Os valores obtidos foram convertidos com o valor de correção da ocular (tambor OSM), que para 40 vezes, aumento utilizado para a medição, é de 0,21599. Foram feitas dez repetições por isolado.

\subsubsection{Caracterização genética}

3.2.2.1 Produção dos isolados de Metarhizium anisopliae, para aplicação da técnica de RAPD (Random Amplified Polymorphic DNA)

Conídios dos isolados foram transferidos para placas de Petri esterilizadas contendo meio de cultura completo (MC) (item 3.1.2). Após a inoculação, as placas foram mantidas em câmara climatizada $\left(26 \pm 1^{\circ} \mathrm{C}\right.$; $80 \pm 5 \%$ UR; 12 horas de fotofase) durante um período de dez dias para crescimento e esporulação do fungo. 
Após o crescimento e esporulação nas placas, os conídios foram retirados com o auxílio de uma espátula estéril, transferindo-se 0,25g do material para frascos contendo $100 \mathrm{~mL}$ do mesmo meio de cultura na forma líquida (sem adição de ágar). Os frascos foram colocados em um agitador mecânico a 220rpm, sob condições controladas de temperatura $\left(26 \pm 2^{\circ} \mathrm{C}\right)$, durante três dias para a produção de micélio, constituindo-se no inóculo utilizado nos testes. O micélio obtido foi submetido à filtração em bomba de vácuo, seco em câmara de fluxo laminar e armazenado em freezer $\left(-40^{\circ} \mathrm{C}\right)$, para posterior extração do DNA.

\subsubsection{Extração do DNA genômico}

$O$ micélio, filtrado e seco, foi triturado em nitrogênio líquido e $0,25 \mathrm{~g}$ desse material colocado em tubos de microcentrífuga de $1,5 \mathrm{~mL}$ em presença de $600 \mu \mathrm{L}$ de tampão de extração ( $4 \mathrm{~mL}$ de Tris- $\mathrm{HCl} 1 \mathrm{M}$ pH8,0,1mL de $\mathrm{NaCl} 5 \mathrm{M}, 1 \mathrm{~mL}$ de EDTA 0,5M e $12 \mathrm{~mL}$ de água destilada). Os tubos foram incubados a $65^{\circ} \mathrm{C}$ por 30 minutos e submetidos a três extrações orgânicas com fenol; fenol: clorofórmio: álcool isoamílico (25:24:1) e clorofórmio: álcool isoamílico (24:1). Nas três extrações foram acrescentados $600 \mu \mathrm{L}$ de cada solvente e os tubos centrifugados a $12.000 \mathrm{rpm}$, durante dez minutos. Após cada centrifugação, foi retirada a fase aquosa e acrescentado $600 \mu \mathrm{L}$ do próximo solvente.

Após as três centrifugações, foi retirada a fase aquosa ao final da extração e adicionado álcool isopropílico (volume igual a 10\% da fase aquosa retirada) e $\mathrm{NaCl}$ (volume igual ao da fase aquosa retirada) para uma 
concentração final de 0,3M. As amostras foram mantidas em freezer $\left(-20^{\circ} \mathrm{C}\right)$ por $12 \mathrm{~h}$. A sedimentação foi feita por centrifugação a $12000 \mathrm{rpm}$ por 10 minutos. O DNA foi lavado com álcool etílico $70 \%$, seco ao ar, ressuspendido em $25 \mu \mathrm{L}$ de TE $(1 \mathrm{~mL}$ de Tris- $\mathrm{HCl} 1 \mathrm{M} \mathrm{pH8,0,200 \mu L}$ de EDTA 0,5M ph8,0 e $799 \mathrm{~mL}$ de água Milli-Q) e armazenado em freezer $-20^{\circ} \mathrm{C}$ (Raeder \& Broda, 1985). O DNA foi quantificado pelo método de fluorescência utilizando-se o fluorímetro Versa Fluor (Bio Rad Laboratories, Hercules, CA $945 \mathrm{H}$, USA) e também em gel de agarose a 0,8\% utilizando um DNA padrão de peso molecular conhecido fago $\lambda$.

\subsubsection{Amplificação RAPD (Random Amplified Polymorphic DNA)}

Foram testados inicialmente sessenta "primers", sendo vinte $e$ quatro desses selecionados, com base no número de bandas obtidas $e$, também, em sua habilidade de produzir fragmentos consistentes, e utilizados para o estudo da variabilidade genética de M. anisopliae (Tabela 2).

Para amplificação do DNA dos isolados de M. anisopliae foram determinados os seguintes componentes de reação em um volume final de

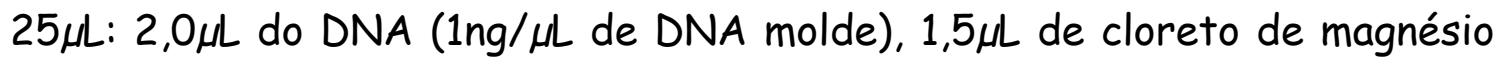

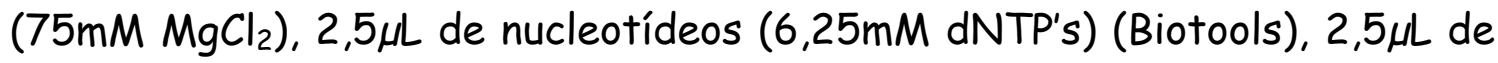

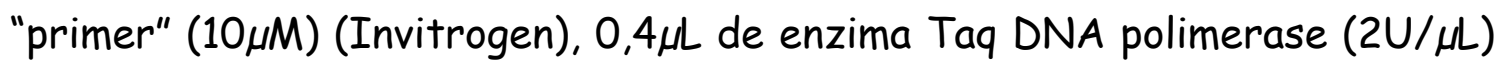
(Biotools), 16,1 $\mu \mathrm{L}$ de água Milli-Q para completar o volume, adicionando-se ao final $0,3 \mu \mathrm{L}$ de óleo mineral. Os valores acima se referem à concentração final de cada reagente para uma reação RAPD. Como controle negativo foi 
utilizada uma amostra que continha todos os reagentes, exceto o DNA do fungo.

As reações foram realizadas em termociclador PTC-100 (MJ Research, Inc., Watertown, MA 02172, USA) nas condições de ampliação: $92^{\circ} \mathrm{C}$ por 5 minutos (1 ciclo), $92^{\circ} \mathrm{C}$ por 40 segundos, $40^{\circ} \mathrm{C}$ por 1,5 minutos $e$ $72^{\circ} \mathrm{C}$ por 2 minutos ( 40 ciclos) e $72^{\circ} \mathrm{C}$ por 5 minutos ( 1 ciclo).

O produto da amplificação foi separado por eletroforese em gel de agarose $(1,4 \%)$, usando tampão TBE (100mM Tris, $83 \mathrm{mM} \mathrm{H} \mathrm{H}_{3} \mathrm{Bo}_{3}$ e $1 \mathrm{mM}$ EDTA) a 3,5 V/cm por 3,5h. Após a eletroforese o gel foi corado em solução de brometo de etídio ( $1 \mu \mathrm{g} / \mathrm{mL}$ de solução) por aproximadamente uma hora e visualizado sob luz ultra violeta (U.V.).

$O$ registro foi feito pela captura da imagem pelo sistema de documentação de gel "Eagle Eye II"(Stratagene, La Jolla, CA 92037,USA), para a estimativa dos pesos moleculares dos locos amplificados. Para evitar problemas relacionados com a variação no número $e$ intensidade dos produtos de amplificação, a comparação entre a mobilidade das bandas foi feita somente dentro de um mesmo gel e baseados em uma mesma reação de RAPD. Bandas correspondentes à amplificação de DNA foram diretamente registradas para todos os iniciadores ("primers") como presentes (valor 1) ou ausentes (valor 0), com todos os 20 isolados testados. Os dados binários foram analisados utilizando-se o coeficiente de similaridade Dice ( $S_{i j}=$ $2 a / 2 a+b+c ; a=+/+$, presença de banda nos indivíduos i e j; $b=+/-$, presença de banda no indivíduo $i$ e ausência no indivíduo $j ; c=-/+$, ausência de banda no indivíduo i e presença no indivíduo j). A partir da matriz de similaridade genética entre os genótipos foi construído um dendrograma pelo critério de 
agrupamento UPGMA (unweighled pair group method with aritimetic average).

Tabela 2. Sequiência dos "primers" selecionados para utilização no RAPD

\begin{tabular}{|c|c|}
\hline "Primer" & Sequiência de bases \\
\hline$C-02$ & $5^{\prime}-G T G A G G C G T C-3^{\prime}$ \\
\hline$C-06$ & $5^{\prime}-G A A C G G A C T C-3^{\prime}$ \\
\hline G-03 & $5^{\prime}-G A G C C C T C C A-3^{\prime}$ \\
\hline G-12 & $5^{\prime}-$ CAGCTCACGA-3' \\
\hline G-13 & $5^{\prime}-C T C T C C G C C A-3^{\prime}$ \\
\hline P-07 & $5^{\prime}-$ GTCCATGCCA-3' \\
\hline P-09 & $5^{\prime}-$ GTGGTCCGCA-3' \\
\hline$P-11$ & $5^{\prime}-A A C G C G T C G G-3^{\prime}$ \\
\hline$P-14$ & $5^{\prime}-C C A G C C G A A C-3^{\prime}$ \\
\hline P-16 & $5^{\prime}-C C A A G C T G C C-3^{\prime}$ \\
\hline P-18 & $5^{\prime}-G G C T T G G C C T-3^{\prime}$ \\
\hline P-19 & $5^{\prime}-G G G A A G G A C A-3^{\prime}$ \\
\hline W-06 & $5^{\prime}-A G G C C C G A T G-3^{\prime}$ \\
\hline$W-20$ & $5^{\prime}-T G T G G C A G C A-3^{\prime}$ \\
\hline$x-07$ & $5^{\prime}-G A G C G A G G C T-3^{\prime}$ \\
\hline$x-11$ & $5^{\prime}-G G A G C C T C A G-3^{\prime}$ \\
\hline$x-12$ & $5^{\prime}-T C G C C A G C C A-3^{\prime}$ \\
\hline$X-17$ & $5^{\prime}-G A C A C G G A C C-3^{\prime}$ \\
\hline$x-19$ & $5^{\prime}-T G G C A A G G C A-3^{\prime}$ \\
\hline$A X-09$ & $5^{\prime}-G G A A G T C C T G-3^{\prime}$ \\
\hline$A X-12$ & $5^{\prime}-G G T C G G G T C A-3^{\prime}$ \\
\hline$A X-16$ & $5^{\prime}-G T C T G T G C G G-3^{\prime}$ \\
\hline$A X-17$ & $5^{\prime}-T G G G C T C T G G-3^{\prime}$ \\
\hline$A X-20$ & $5^{\prime}-A C A C T C G G C A-3^{\prime}$ \\
\hline
\end{tabular}




\section{RESULTADOS E DISCUSSÃO}

\subsection{Patogenicidade de isolados de Metarhizium anisopliae a Mahanarva fimbriolata}

Os termos patogenicidade e virulência são usados em muitas disciplinas científicas e a definição destes termos pode causar confusão. Em patologia de insetos a patogenicidade de um fungo é a capacidade intrínsica do microrganismo penetrar às defesas do hospedeiro, ou seja, a capacidade do microrganismo de provocar doença. É uma característica genética e qualitativa do microrganismo. E virulência é a velocidade com a qual o microrganismo penetra as defesas do hospedeiro, pode também ser chamada

de agressividade. É uma característica biológica alterável e representa a intensidade ou o grau com o que o patógeno causa a doença (Alves \& Lecuona, 1998; Thomas \& Elkinton, 2004).

Todos os isolados mostraram-se patogênicos para a M. fimbriolata. As mortalidades corrigidas das ninfas variaram de 10,5 a $60 \%$ para os isolados testados (Tabela 3). Os mais patogênicos foram o IBCB-384, IBCB348, ESALQ 1285, IBCB-345, ESALQ 319 e ESALQ 1037 que causaram mortalidades médias de 59,7; 59,5; 57,9; 58,4; 53,9 e 46,5\%, respectivamente (Figura 3 ). 
Tabela 3. Isolados, hospedeiro original, local de origem e mortalidade corrigida (\%) de Metarhizium anisopliae a ninfas de Mahanarva fimbriolata

\begin{tabular}{|c|c|c|c|}
\hline Isolado & Hospedeiro & Origem & $\begin{array}{l}\text { Mortalidade } \\
\text { Corrigida (\%) }\end{array}$ \\
\hline ESALQ 319 & M. posticita & Goânia- PE & 53,9 \\
\hline ESALQ 935 & D. saccharalis & Itabuna - BA & 33,0 \\
\hline ESALQ 1037 & Solenopsis sp. & Porto Alegre - RS & 46,5 \\
\hline ESALQ 1204 & M. fimbriolata & Piracicaba - SP & 33,0 \\
\hline ESALQ 1286 & M. fimbriolata & Valparaíso - SP & 57,9 \\
\hline ESALQ 1294 & Cercopidae & Guaira - SP & 18,5 \\
\hline ESALQ 1301 & M. fimbriolata & Iturama- $M G$ & 33,7 \\
\hline ESALQE9 & M. posticata & Boca da Mata - AL & 38,6 \\
\hline ESALQ PL26 & M. posticata & Nordeste & 11,5 \\
\hline ESALQ PL43 & M. posticata & Fleixeira Del Estado - AL & 33,6 \\
\hline ESALQ PL49 & M. posticata & Nordeste & 31,7 \\
\hline IBCB - 333 & M. fimbriolata & Valparaíso - SP & 46,9 \\
\hline IBCB - 334 & M. fimbriolata & Novo Horizonte - SP & 28,0 \\
\hline IBCB - 345 & M. fimbriolata & Cosmópolis - SP & 33,7 \\
\hline IBCB - 348 & M. fimbriolata & Sertãozinho - SP & 58,4 \\
\hline IBCB - 353 & M. fimbriolata & Valparaíso - SP & 59,4 \\
\hline IBCB - 374 & M. fimbriolata & Sertãozinho - SP & 47,7 \\
\hline IBCB -380 & M. fimbriolata & Água Branca - SP & 19,8 \\
\hline IBCB - 384 & M. fimbriolata & Sertãozinho - SP & 10,4 \\
\hline IBCB - 391 & M. fimbriolata & Tabapuã - SP & 59,7 \\
\hline
\end{tabular}


A virulência e especificidade ao hospedeiro são duas características essenciais na seleção de um microrganismo apropriado ao uso no controle microbiano (Devi et al., 2001). Isolados diferentes preservados durante uma epizootia, numa mesma área, procedentes da mesma espécie de inseto hospedeiro mostram diferenças quanto a patogenicidade $e$ agressividade nesta mesma espécie de inseto quando testados em laboratório (Berretta et al., 1998). No presente trabalho evidenciou-se esse fato, uma vez que a maioria dos isolados testados era proveniente de uma mesma espécie de inseto e mostraram-se diferentes quanto a patogenicidade em testes de laboratório, quanto à morfologia das colônias e às características genéticas.

A maioria dos trabalhos de seleção de isolados não correlaciona a patogenicidade e virulência de um determinado isolado ao seu local de origem ou hospedeiro. Normalmente esses isolados causam altos índices de mortalidade a uma ampla gama de hospedeiros como foi observado para Heterotermes tenuis, pragas de grãos armazenados, Tetranychus urticae, Frankliniella occidentalis, Bemisia tabaci, Brevipalpus phoenicis entre outros (Almeida et al. , 1997: Moino Júnior et al., 1998; Tamai, 1998; Lopes, 1999; Ramos, 2001; Rossi, 2002). A variação da mortalidade pode ser observada, com frequiência, em bioensaios de seleção e pode estar associada a fatores como patogenicidade, virulência, especificidade, tolerância do hospedeiro, entre outros (Alves, 1998). Diferenças na patogenicidade são indicativas de ocorrência natural de variação genética. Essa variação tem sido identificada em outros caracteres além da patogenicidade que incluem a dimensão dos 
conídios, taxas de crescimento e atividades enzimáticas (St. Leger et al., 1992).

Alguns pesquisadores acreditam que a especialização ao hospedeiro não pode ser considerada como critério taxonômico, pois $M$. anisopliae é um patógeno facultativo o qual não está estritamente ligado a seu hospedeiro original (Yip et al., 1992) e sua virulência pode ser o resultado de um conjunto de enzimas inespecíficas atuando juntas (Vargas et al., 2003).

Os resultados obtidos evidenciam a importância de efetuar bioensaios para a seleção de isolados antes do desenvolvimento de um produto microbiano. Esses bioensaios devem avaliar também a virulência do patógeno visando selecionar dentre os patógenos, o que apresente maior patogenicidade e virulência (Alves, 1998). 


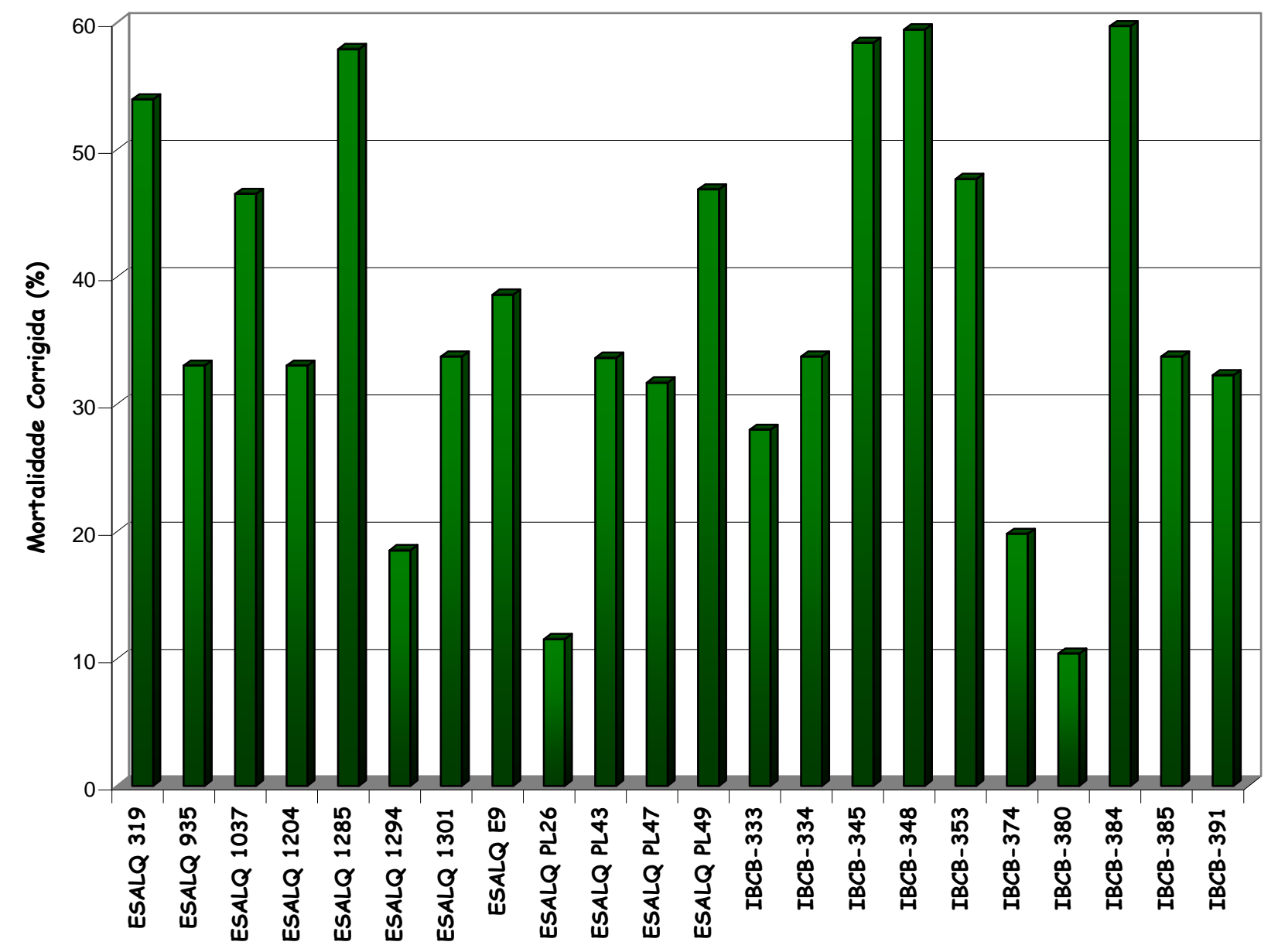

Figura 3 - Mortalidade corrigida (\%) de Mahanarva fimbriolata causada pelos diferentes isolados de Metarhizium anisopliae 
O método de bioensaio utilizado, com raízes de mudas de cana-deaçúcar como substrato para as ninfas, mostrou-se muito eficiente, uma vez que a mortalidade da testemunha foi menor que a apresentada em testes preliminares onde as ninfas pulverizadas eram mantidas em placas de Petri (14cm de diâmetro) e alimentadas com folhas de cana. Isso se deve, provavelmente, ao alimento das ninfas, que no campo, é a seiva das raízes. Ao final das avaliações as mudas de cana mostravam-se com sintomas severos de ataque da praga, comprovando que as ninfas alimentaram-se das plantas.

A mortalidade pelo fungo pôde ser confirmada pelo exame das ninfas e adultos contaminados que foram mantidos em câmara úmida após a morte. Houve a completa colonização do fungo e sua posterior esporulação como se observa na Figura 4A. Observou-se também que algumas ninfas não sofreram ecdise, uma vez que foram colonizadas pelo fungo (Figura 4B). 

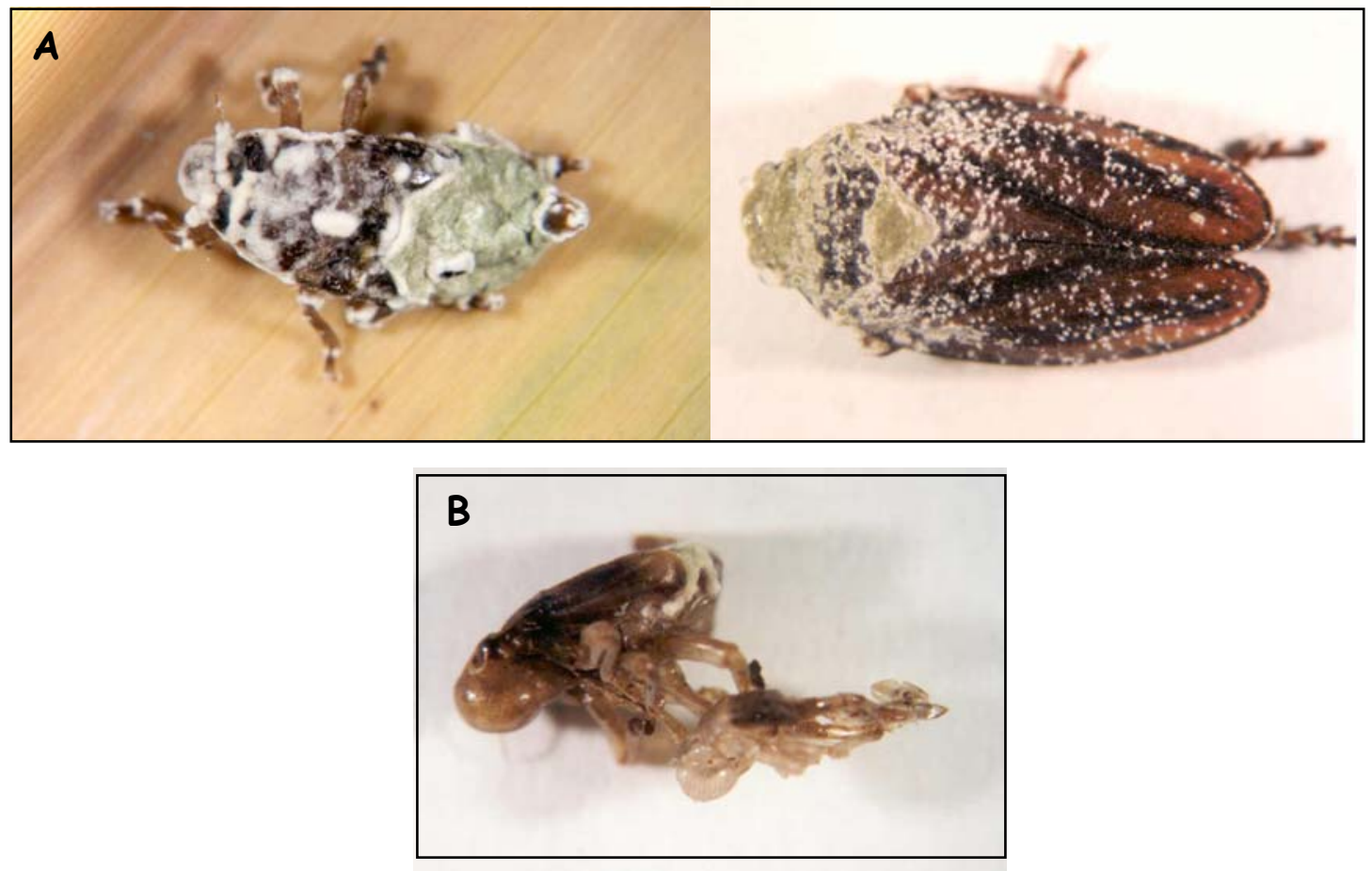

Figura 4 - A) Ninfa e adulto de Mahanarva fimbriolata infectados com Metarhizium anisopliae; B) Interferência do fungo Metarhizium anisopliae no processo de ecdise de ninfa de Mahanarva fimbriolata

\subsubsection{Produção dos isolados de Metarhizium anisopliae pelo método da bandeja}

Os isolados que causaram mortalidade elevada e que apresentaram maior crescimento e esporulação, parâmetros observados durante a produção dos inóculos para a seleção (Figura 5), foram colocados em teste de produção massal em bandejas visando à seleção dos mais produtivos para esse processo. Na prática, tanto meio sólido quanto culturas submersas 
estão sendo utilizadas para a produção massal de Metarhizium. Porém, o meio sólido, utilizando arroz pré-cozido como substrato é mais fácil, mais produtivo e econômico (Zimmermann, 1993; Pereira \& Alves, 1998).
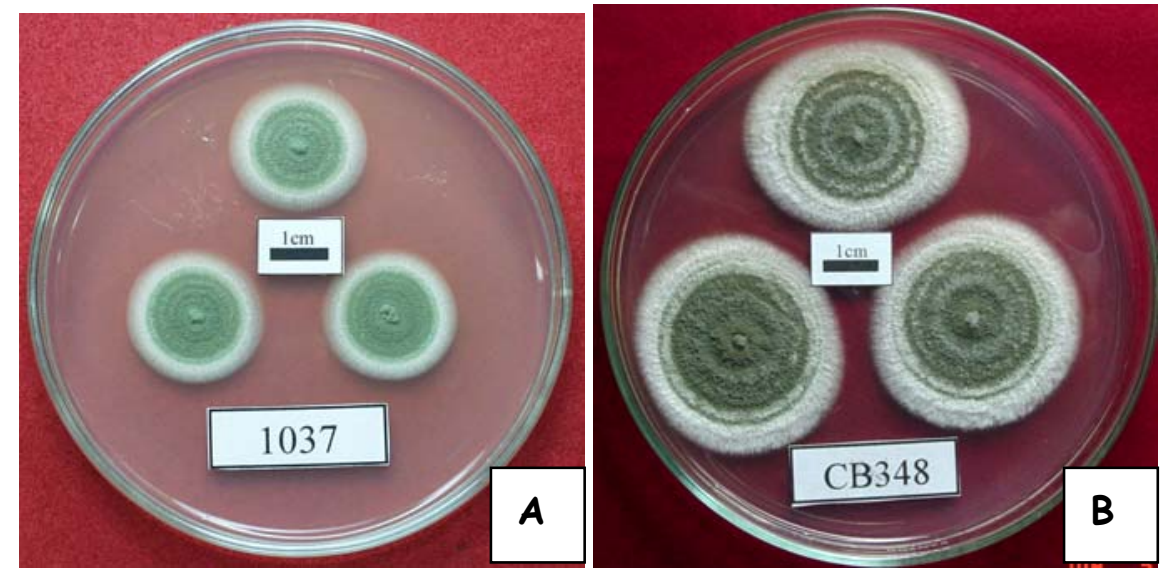

Figura 5 - Características culturais de Metarhizium anisopliae isolado ESALQ 1037 (A) e isolado IBCB-348 (B) aos oito dias após a inoculação

A análise dos resultados, pelo teste de Tukey a $5 \%$ de probabilidade demonstra que a produção de conídios do isolado ESALQ 1037, pelo método de bandeja, diferiu estatisticamente da produção de conídios do isolado IBCB-348 nas mesmas condições (Tabela 4). 
Tabela 4. Média do número de conídios por grama dos isolados de Metarhizium anisopliae produzidos massalmente pelo método de bandeja

\begin{tabular}{cc}
\hline Isolados & Média $\left(\times 10^{9}\right.$ conídios $/ g$ de arroz $)$ \\
ESALQ 1037 & $3,49 \mathrm{a}^{*}$ \\
IBCB-348 & $2,29 \mathrm{~b}$ \\
\hline Valor $F$ & 6,53 \\
CV(\%) & 34,4
\end{tabular}

* Médias seguidas de mesma letra não diferem entre si pelo teste de Tukey $(P<0.05)$

Assim, o isolado ESALQ 1037, apresentou elevada patogenicidade para M. fimbriolata e excelente produção em bandejas. Esses resultados coincidem com os trabalhos realizados pela ESALQ/Itaforte Bioprodutos visando o desenvolvimento do produto Metarril, formulado com esse isolado, para o controle desta praga em cana-de-açúcar.

\subsection{Caracterização morfológica e genética dos isolados de Metarhizium anisopliae}

\subsubsection{Caracterização morfológica}

As colônias dos isolados de M. anisopliae apresentaram coloração que variou de verde acinzentado até verde escuro (oliva). Alguns isolados apresentaram crescimento micelial mais denso e mais proeminente (aspecto "cotonoso") (Figura 6). Essas características foram observadas por Yip et al. 
(1992) que estudou 204 culturas de M. anisopliae isoladas de solos de pastagem da Tasmânia. Os autores observaram três cores básicas da colônia após a esporulação: verde acinzentado, cinza escuro e verde escuro. A cor da colônia foi observada por ser um caráter estável e é considerada uma característica confiável para a separação de isolados (Yip et al., 1992).

$O$ crescimento das colônias (diâmetro) que variou de $28 \mathrm{~mm}$ para 0 isolado IBCB-353 à $38 \mathrm{~mm}$ para o isolado IBCB-348 após oito dias de crescimento.
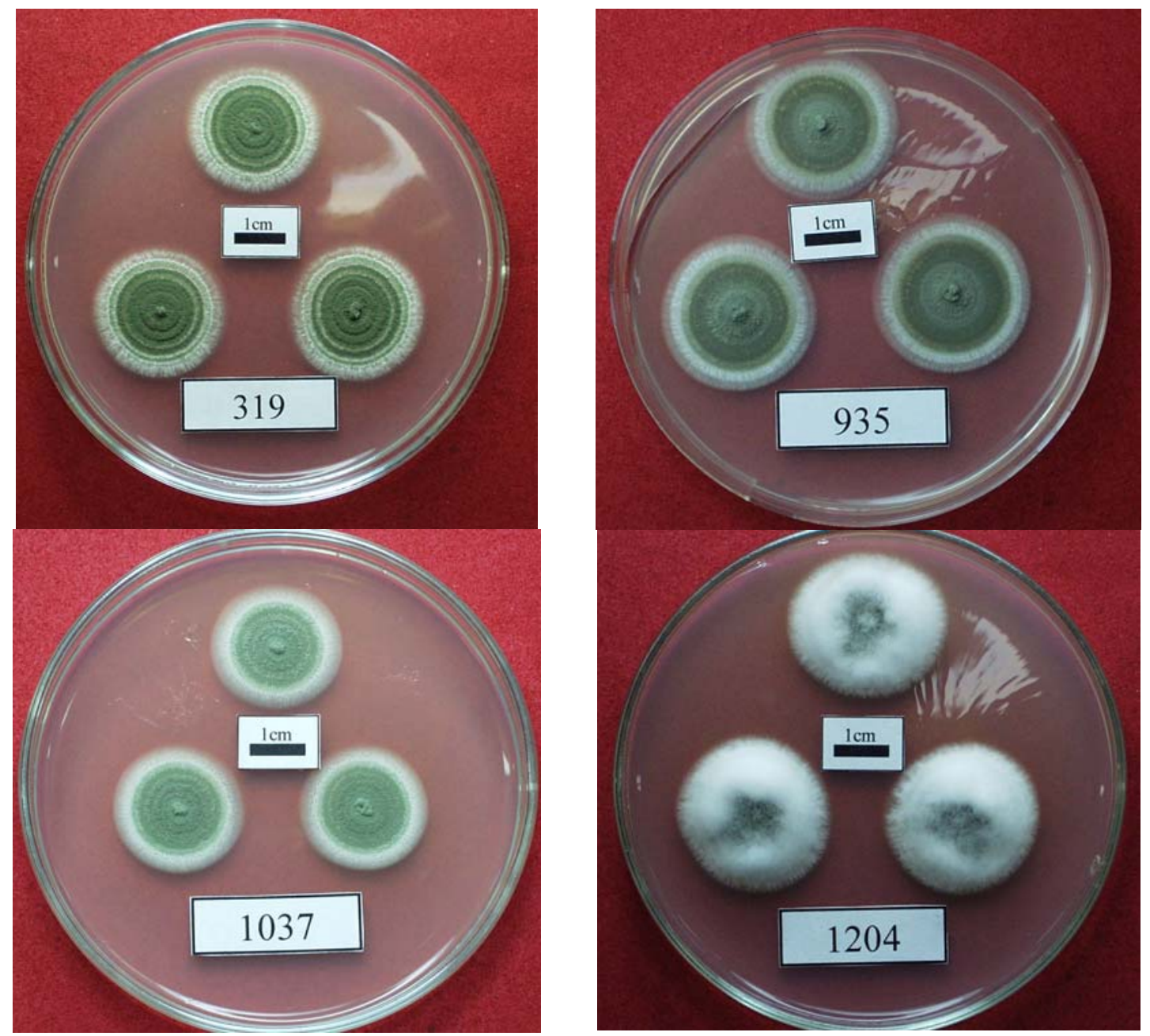

Figura 6 - Crescimento e esporulação das colônias de Metarhizium anisopliae aos após oito dias da inoculação em meio de cultura 

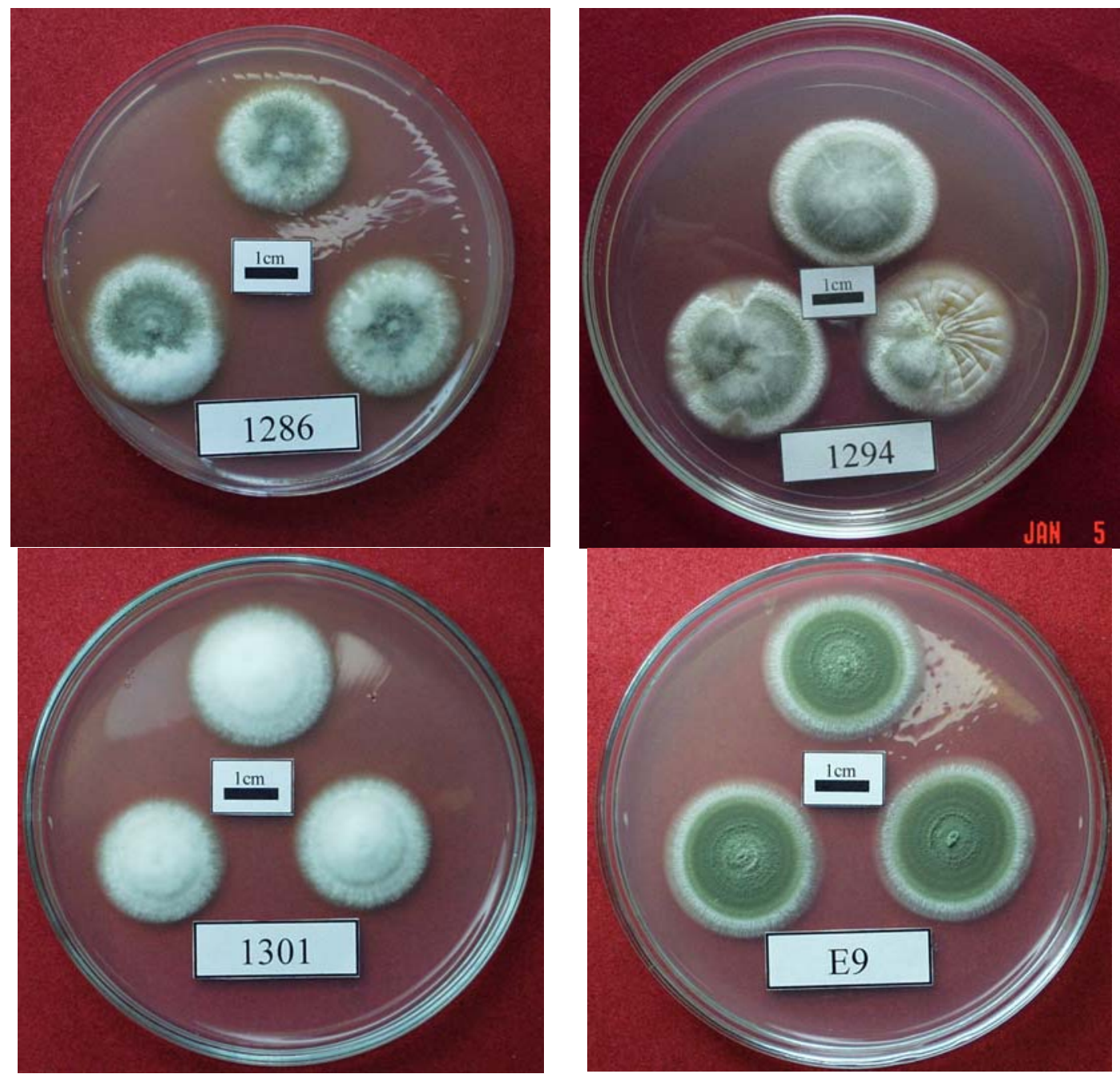

Figura 6 - Crescimento e esporulação das colônias de Metarhizium anisopliae aos após oito dias da inoculação em meio de cultura 

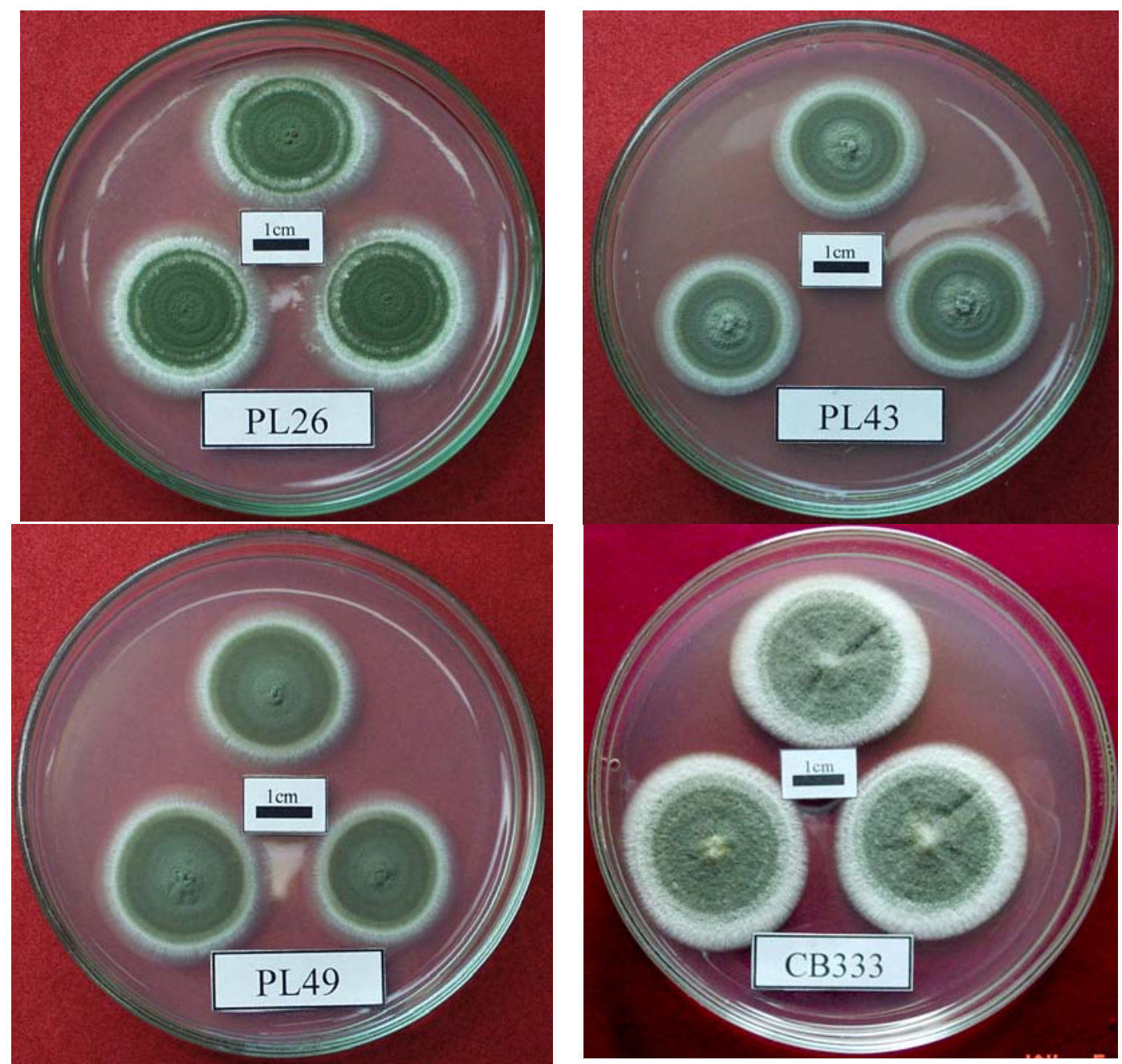

Figura 6 - Crescimento e esporulação das colônias de Metarhizium anisopliae aos após oito dias da inoculação em meio de cultura 

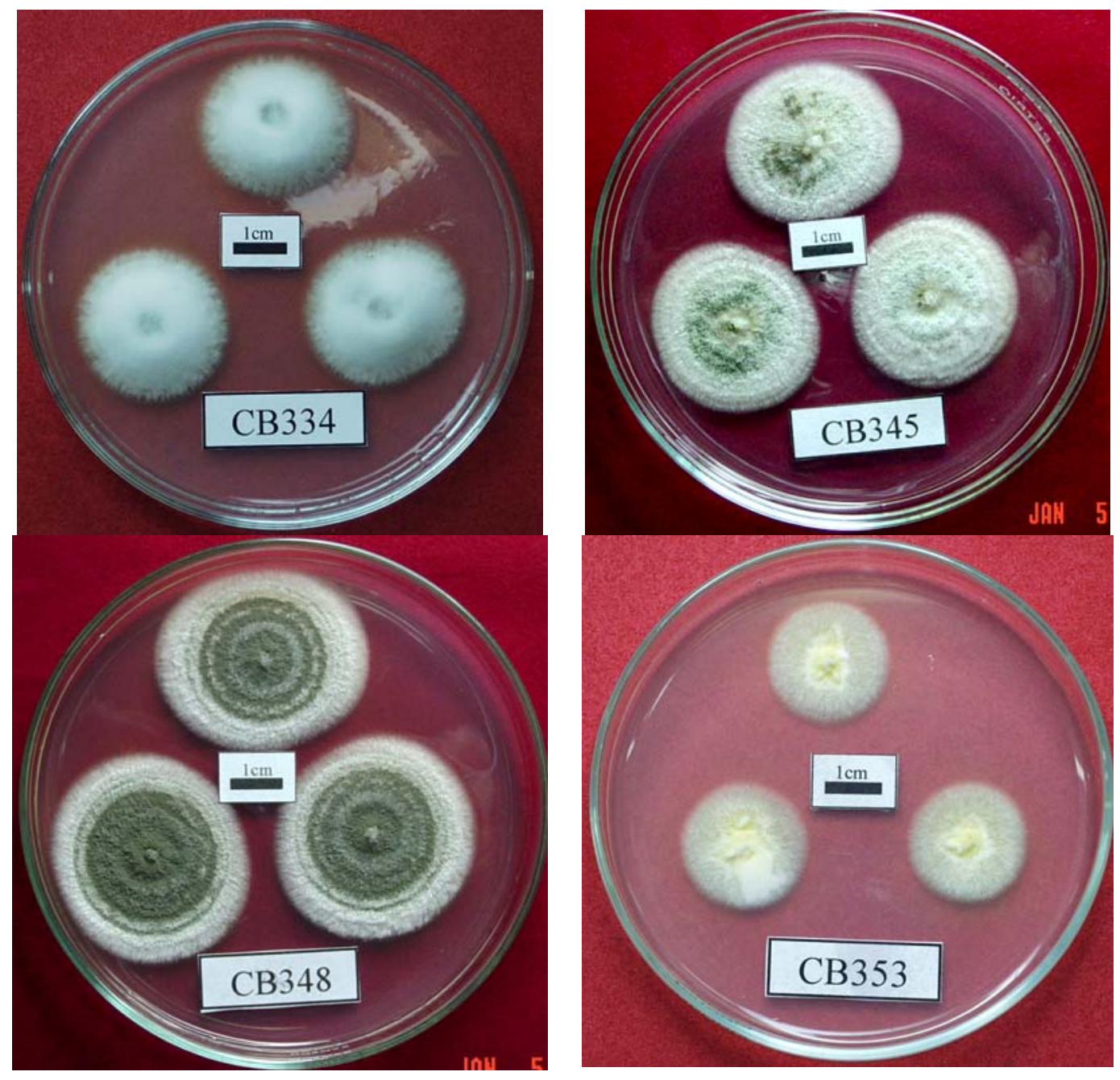

Figura 6 - Crescimento e esporulação das colônias de Metarhizium anisopliae aos após oito dias da inoculação em meio de cultura 

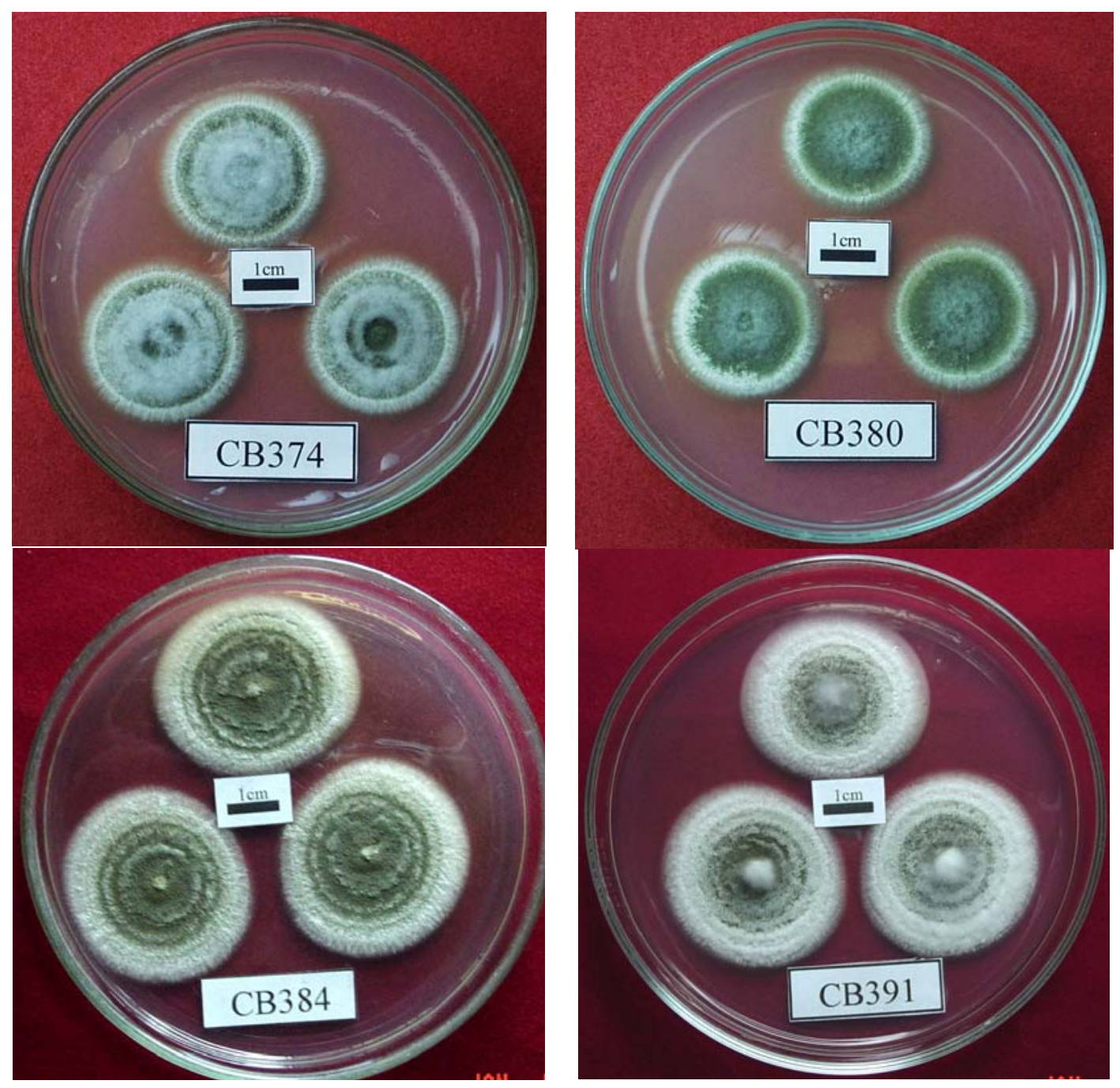

Figura 6 - Crescimento e esporulação das colônias de Metarhizium anisopliae aos após oito dias da inoculação em meio de cultura 
O exame das estruturas dos conidióforose conídios mostraram que todos os isolados pertencem à espécie M. anisopliae. Assim apresentando conidióforos simples que, justapostos, resultam em uma massa regular. As fiálides, clavadas ou cilíndricas são originárias do vértice de hifas e se colocam uma ao lado das outras (Alves, 1998) (Figura 7).
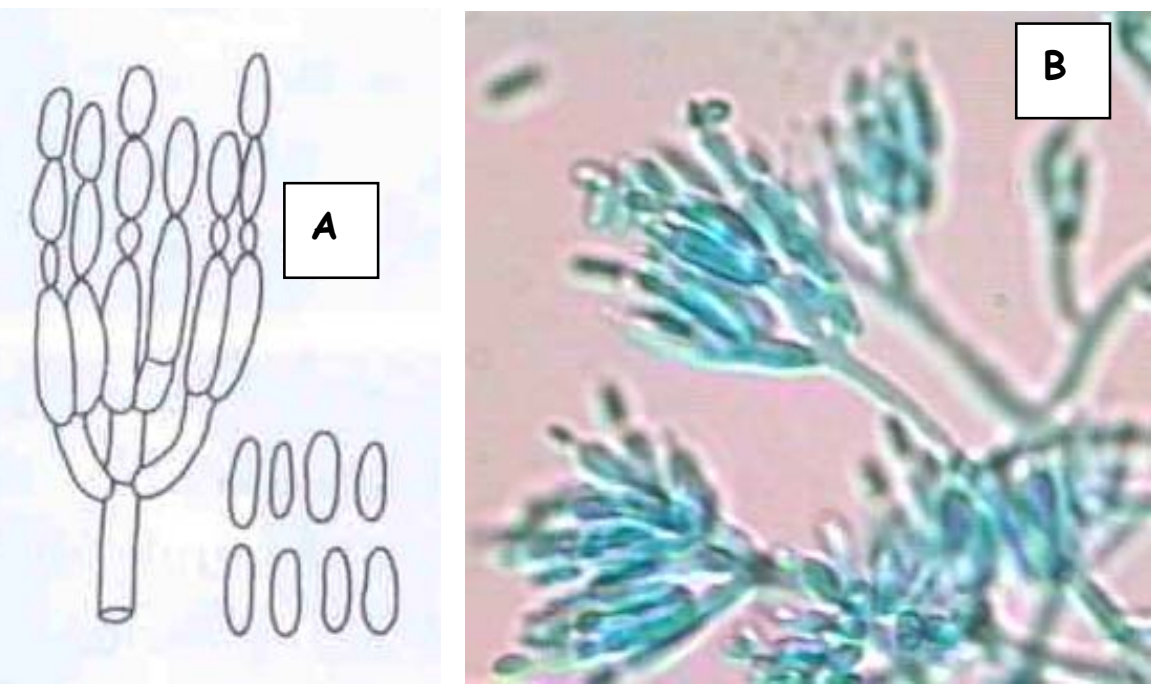

Figura 7 - A) Conidióforo de Metarhizium anisopliae (Alves, 1998); B) Foto do conidióforo do isolado ESALQ 1037 de Metarhizium anisopliae

O estudo dos conídios de fungos entomopatogênicos é importante, pois eles são responsáveis pelo início da infecção no inseto e são, portanto, o ingrediente ativo das formulações de micoinseticidas (Jeffs et al., 1999).

As dimensões dos conídios variaram entre 5,465 e 7,970 $\mu \mathrm{m}$ comprimento para os isolados IBCB-345 e ESALQ 1301, respectivamente 
(Tabela 5). Não é possível inferir que a patogenicidade seja influenciada pela dimensão dos conídios, uma vez que conídios que apresentaram tamanhos diferentes causaram mortalidade igual à mesma espécie de inseto testado como, por exemplo, os isolados IBCB-345, com conídio de $5,465 \mu \mathrm{m}$ de comprimento e mortalidade $58,4 \%$, e IBCB-384, com conídios de $7,538 \mu \mathrm{m}$ de comprimento e mortalidade $59,7 \%$. Observou-se também que conídios com mesmo tamanho causaram mortalidades diferentes como para os isolados ESALQ 935 e ESALQ 1294, com conídios de 6,069 $\mu \mathrm{m}$ de comprimento e mortalidades de 33 e 18,5\%, respectivamente. Tulloch (1976) descrevendo e classificando as espécies de Metarhizium, relatou que o tamanho do conídio diferencia espécies e subespécies, mas não influencia em sua infectividade.

Riba et al. (1986) comparando as dimensões de conídios de 96 isolados de M. anisopliae observaram que os mesmos variaram entre 3,5 a $17,7 \mu \mathrm{m}$ de comprimento. A maioria dos isolados (74) possuía esporos pequenos, com comprimento variando de 3,4 a $5 \mu \mathrm{m}$ (var. anisopliae). Treze deles possuíam conídios com pelo menos $11 \mu$ m (var. majus) e outros nove tinham comprimento intermediário entre os dois grupos previamente descritos. Yip et al. (1992) caracterizando Metarhizium isolados de solos da Tasmânia observaram conídios com dimensões de 5 a $9 \mu m$ de comprimento.

Todos os isolados de M. anisopliae estudados possuem morfologia cilíndrica similar e o mesmo foi observado por Jeffs et al. (1999). Pelos resultados obtidos pode-se concluir que todos os isolados estudados pertencem à espécie M. anisopliae var. anisopliae com conídios de forma curta, com tamanho que varia de 6 a $8 \mu \mathrm{m}$ de comprimento (Tulloch, 1976). 
Tulloch (1976) estudando o crescimento de isolados, de conídio longo e de conídio curto, em diferentes meios de cultura (em arroz e em dextrose-ágar) verificou que não houve diferenças significativas no comprimento dos conídios de colônias crescidas em cada meio de cultura. A dimensão dos conídios é importante na separação de isolados próximos, mas não pode ser uma característica avaliada isoladamente (Yip et al., 1992).

Driver et al. (2000) concluíram que a morfologia do conídio tinha como único potencial de uso a classificação morfológica dos isolados de Metarhizium testados e sugerem que o tamanho dos conídios seja útil na determinação das espécies.

Jeffs et al. (1999) pesquisando a relação entre a morfologia dos conídios e as propriedades da superfície dos mesmos, de diferentes gêneros de fungos entomopatogênicos, incluindo Metarhizium, concluíram que esse tipo de estudo contribui para o entendimento da especialização de alguns isolados a determinados hospedeiros. 
Tabela 5. Comprimento médio dos conídios dos isolados de Metarhizium anisopliae

\begin{tabular}{|c|c|}
\hline Isolado & Comprimento médio dos conídios $(\mu \mathrm{m})$ \\
\hline ESALQ 319 & 7,473 \\
\hline ESALQ 935 & 6,069 \\
\hline ESALQ 1037 & 6,437 \\
\hline ESALQ 1204 & 7,646 \\
\hline ESALQ 1286 & 7,905 \\
\hline ESALQ 1294 & 6,069 \\
\hline ESALQ 1301 & 7,970 \\
\hline ESALQE9 & 6,933 \\
\hline ESALQ PL26 & 7,257 \\
\hline ESALQ PL43 & 6,048 \\
\hline ESALQ PL49 & 6,437 \\
\hline IBCB-333 & 7,538 \\
\hline IBCB-334 & 6,717 \\
\hline IBCB-345 & 5,465 \\
\hline IBCB-348 & 6,501 \\
\hline IBCB-353 & 6,868 \\
\hline IBCB-374 & 6,588 \\
\hline IBCB-380 & 7,473 \\
\hline ICBC-384 & 7,538 \\
\hline ICBC-391 & 6,933 \\
\hline
\end{tabular}




\subsubsection{Caracterização genética}

A maioria das pesquisas com fungos entomopatogênicos tem sido feita avaliando-se patogenicidade, usualmente por inoculação de isolados de fungos a diversas espécies de hospedeiros. Esse método torna difícil a elucidação da base genética, pois os resultados podem ser confundidos e/ou influenciados por variáveis do ambiente, pelo processo de colonização do fungo e pela variabilidade genética do hospedeiro em resposta ao parasitismo (St. Leger et al., 1992).

Durante a quantificação do DNA genômico extraído de $M$. anisopliae, dos vinte isolados estudados, em onze deles (ESALQ E9, IBCB353; IBCB-333, IBCB-380, IBCB-345, IBCB-374, ESALQ 1294，ESALQ 1204, ESALQ 319, ESALQ PL26 e ESALQ 1301) observou-se à presença de RNA de fita dupla (Figura 8). Isso significa, provavelmente, a ocorrência de um vírus associado a esses isolados. Em tese, todos os seres vivos devem ser suscetíveis a vírus e esse parasitismo, em geral, resulta em prejuízo para a célula/organismo (Ribeiro et al., 1998). Bogo et al. (1996) citaram que cerca de $30 \%$ de todas as espécies de fungos convivem com a presença de vírus. Em alguns casos eles interagem com seu hospedeiro (fungo) de forma benéfica e em outros interferem nas atividades desses organismos. $O$ efeito desse RNA de fita dupla (vírus) tem sido estudado, principalmente, em espécies de fungos patogênicos a plantas.

A presença de vírus em M. anisopliae já foi detectada por Leal et al. (1994b) em dois isolados. Entretanto, não tem sido pesquisado se a 
presença dessas partículas reduz a virulência do fungo (Martins et al., 1999).

Martins et al. (1999) detectaram a presença de vírus em cinco dos sete isolados de M. flavoviridae estudados. Os autores cultivaram duas linhagens de cada isolado, uma com a presença e outra com ausência de RNA de fita dupla, e testaram sua patogenicidade a Rhammatocerus schistocercoides e observaram a ausência de efeitos de hipovirulência dos isolados de M. flavoviridae com presença de RNA de fita dupla.

No presente estudo, ocorreram diferenças na patogenicidade dos isolados a M. fimbriolata, mas isso, provavelmente, não teve influência do vírus. Observou-se apenas que os isolados que apresentavam RNA de fita dupla foram mais lentos no tempo de conidiogênese, além de apresentar menor esporulação. Portanto, para os isolados testados observou-se que a presença do vírus interfere mais na produção do fungo do que em sua virulência. $O$ crescimento mais lento e a menor esporulação ficaram mais evidentes quando o fungo cresceu em meio B.D.A. do que em meio M.C., por ser menos nutritivo (Figura 9). Porém, estudos mais detalhados devem ser realizados, criando linhagens do mesmo isolado, com e sem o vírus para a comprovar estes fatos. 


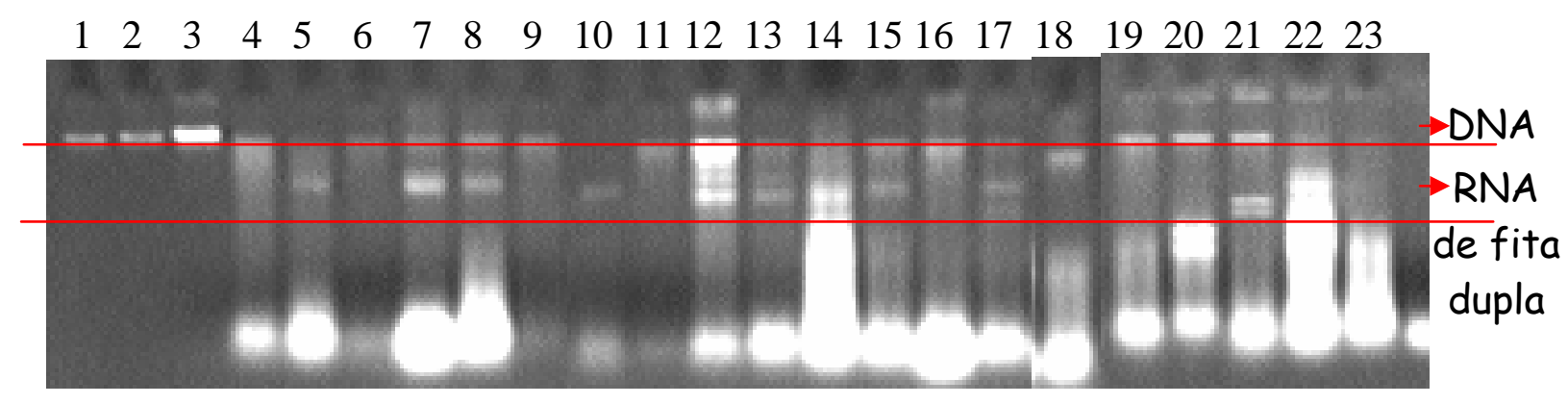

Figura 8 - Estimativa da concentração de DNA genômico em gel de eletroforese colorido com brometo de etídio, detectando a presença de RNA de fita dupla em onze dos vinte isolados de Metarhizium anisopliae. (Sequiência dos isolados no gel: DNA padrão, concentração 1, 2 e 3; isolados: ESALQ 1037 (4); ESALQ E9 (5); IBCB-348 (6); IBCB-353 (7); IBCB-333 (8); IBCB-391 (9); IBCB-380 (10); IBCB-334 (11); IBCB-345 (12); IBCB-374 (13); ESALQ 1294 (14); ESALQ 1204 (15); ESALQ 1286 (16); ESALQ 319 (17); ESALQ PL43 (18); ESALQ 935 (19); ESALQ PL49 (20); ESALQ PL26 (21); ESALQ 1301 (22) e IBCB-384 (23)) 

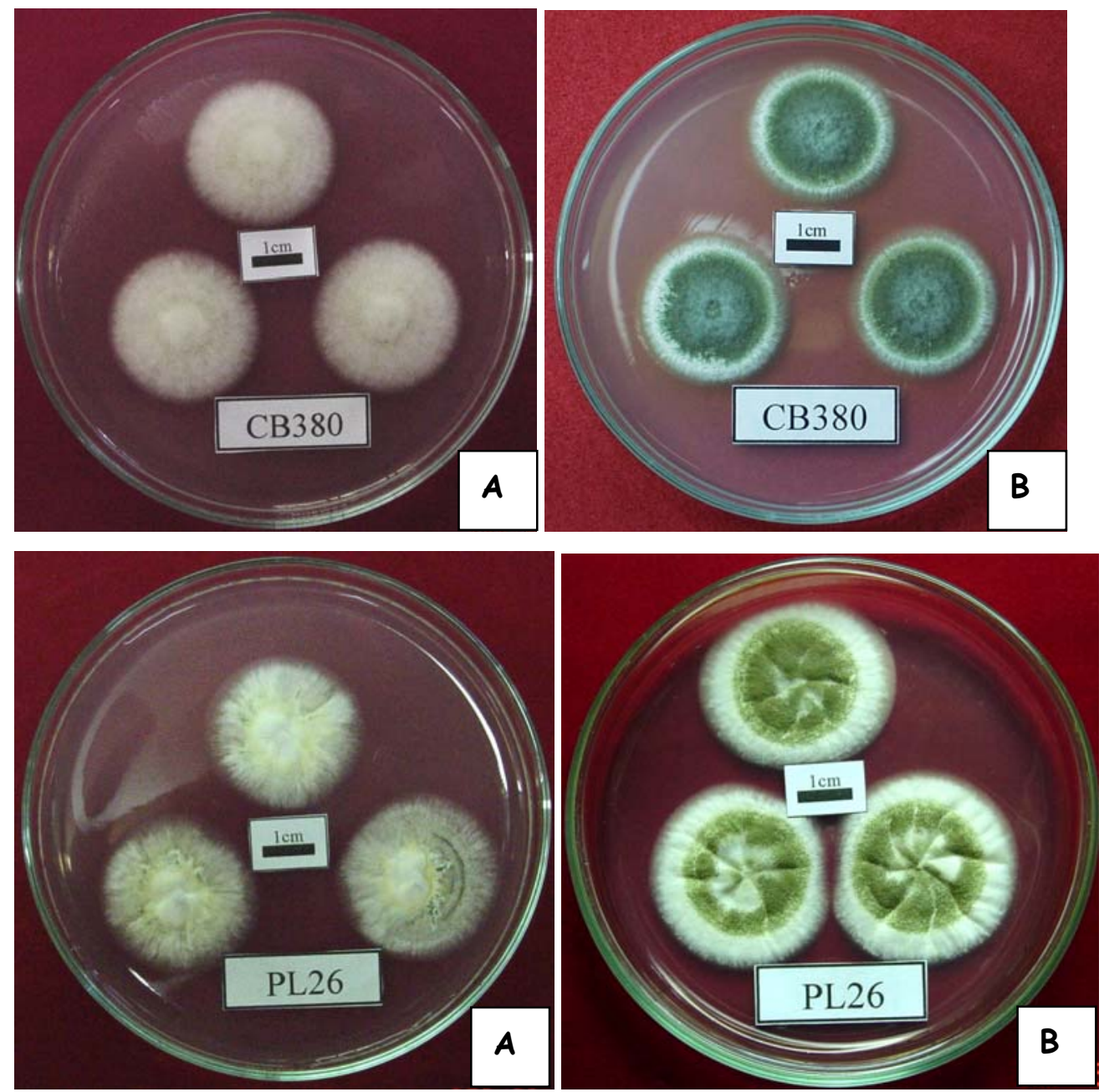

Figura 9 - Características culturais de isolados com presença de RNA de fita dupla em meio B.D.A. (A) e em meio M.C. (B) 
A análise de RAPD foi conduzida usando DNA genômico extraído como descrito no item 3.2.2.2. As amplificações do DNA dos 20 isolados de M. anisopliae com os "primers" C-02; C-06; G-03; G-12; G-13; P-07; P-09; P11; P-14; P-16; P-18; P-19; W-06; W-20; X-07; X-11; X-12; X-17; X-19; AX09: AX-12; $A X-16 ; A X-17 ; A X-20$ deram origem a um total de 199 bandas (Figura 10). O maior número de produtos de amplificação (11 bandas) foi observado com os "primers" G-13, X-12 e AX-17. Em nível de 72,5\% de similaridade, os 20 isolados constituíram dois grupos (grupo $A$ e B), sendo observada a composição de dois subgrupos (B1 e B2) dentro do grupo B. No subgrupo B1, composto de oito isolados, foi observada variação de 0,81 a 0,88 na similaridade. Valores semelhantes na amplitude de similaridade foram também observados dentro do subgrupo $B 2(0,79$ a 0,90$)$, composto por nove isolados (Figura 11). A alta similaridade entre os dois subgrupos $e$ dentro de cada um deles pode indicar que os isolados pertencem à mesma subespécie. Fegan et al. (1993), utilizando um isolado de M. anisopliae var. majus como padrão, observaram alta dissimilaridade (74\%) desse isolado com outros de M. anisopliae var. anisopliae. Contudo, os autores constataram ainda que o padrão não foi o isolado mais diferente geneticamente entre os 31 testados. Essa discussão evidencia claramente a importância de correlacionar os estudos por RAPD com parâmetros morfológicos $e$ biológicos de diferentes isolados de fungos entomopatogênicos. 

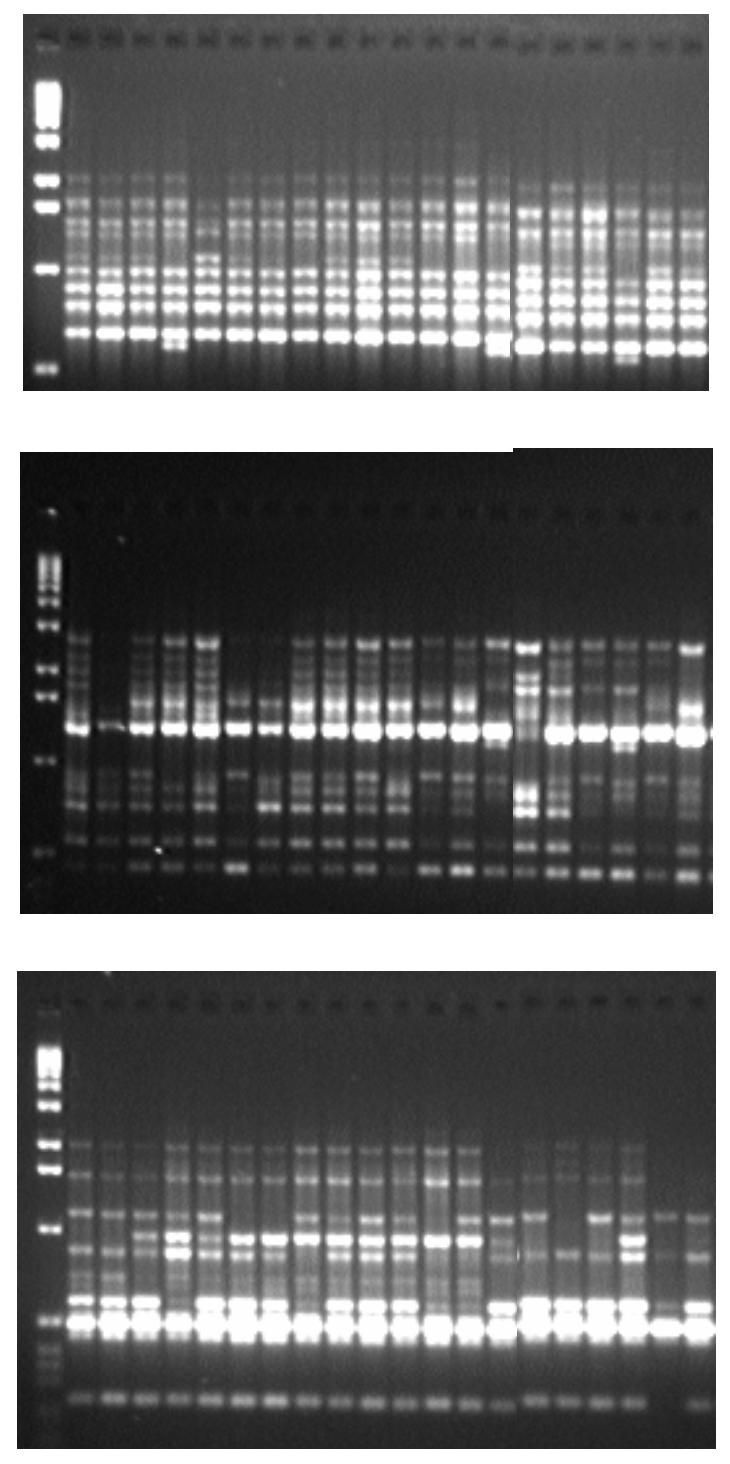

Figura 10 - Perfis de RAPD dos isolados de Metarhizium anisopliae, ESALQ 1037: ESALQ E9; IBCB-348; IBCB-353; IBCB-333; IBCB-391; IBCB-380; IBCB-334; IBCB-345; IBCB-374; ESALQ 1294; ESALQ 1204: ESALQ 1286: ESALQ 319; ESALQ PL43; ESALQ 935: ESALQ PL49; ESALQ PL26: ESALQ 1301 e IBCB-384, obtidos com os "primers" G-13, AX-17 e P-09, respectivamente 


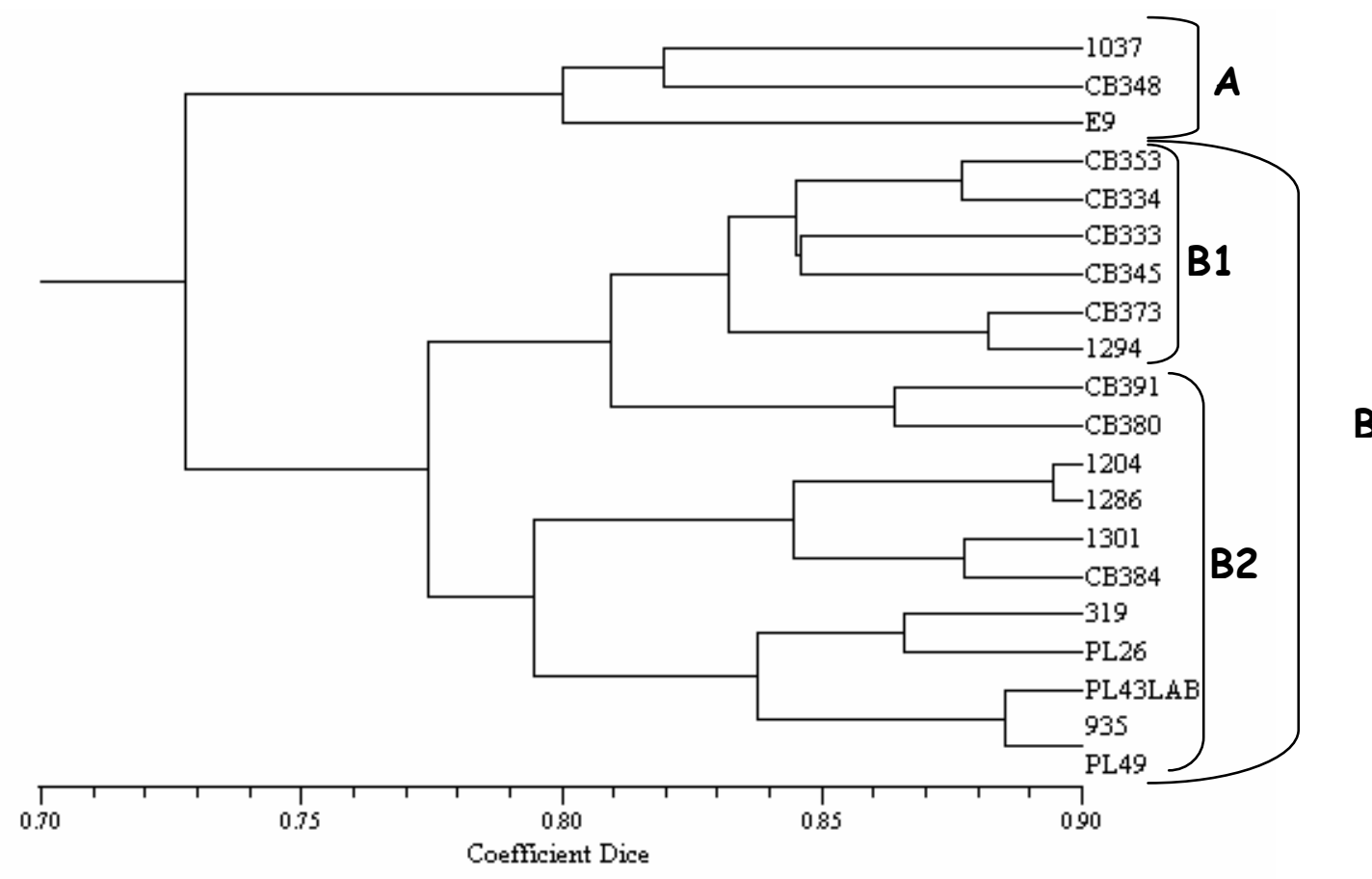

Figura 11 - Dendrograma construído pelo método de agrupamento UPGMA a partir da matriz de similaridade obtida pelo coeficiente Dice ilustrando a relação entre 20 isolados de Metarhizium anisopliae

A variabilidade genética intraespecífica pode também ser avaliada medindo a atividade enzímica de diferentes isolados do patógeno. Sosa Gomes \& Alves (1983) determinaram a atividade aminolítica, proteolítica e lipolítica de onze isolados de M. anisopliae e sua correlação com a eficiência de controle de lagartas de D. saccharalis.

Pode-se observar que mesmo entre os dois grupos ( $A$ e $B$ ) existe alta similaridade $(0,72)$. Os resultados podem sugerir que os isolados pertençam a uma mesma subespécie. Isso foi confirmado pelo tamanho dos 
conídios, como discutido no item 4.2 onde se verificou que todos os isolados testados de M. anisopliae pertencem à variedade anisopliae. Parâmetros morfológicos, relacionados ao crescimento, forma e coloração das colônias, podem ser importantes indicadores da variabilidade entre isolados (Alves et al., 1986). Mesmo havendo alta similaridade, características morfológicas bem distintas foram observadas para todos os isolados (Figura 12).
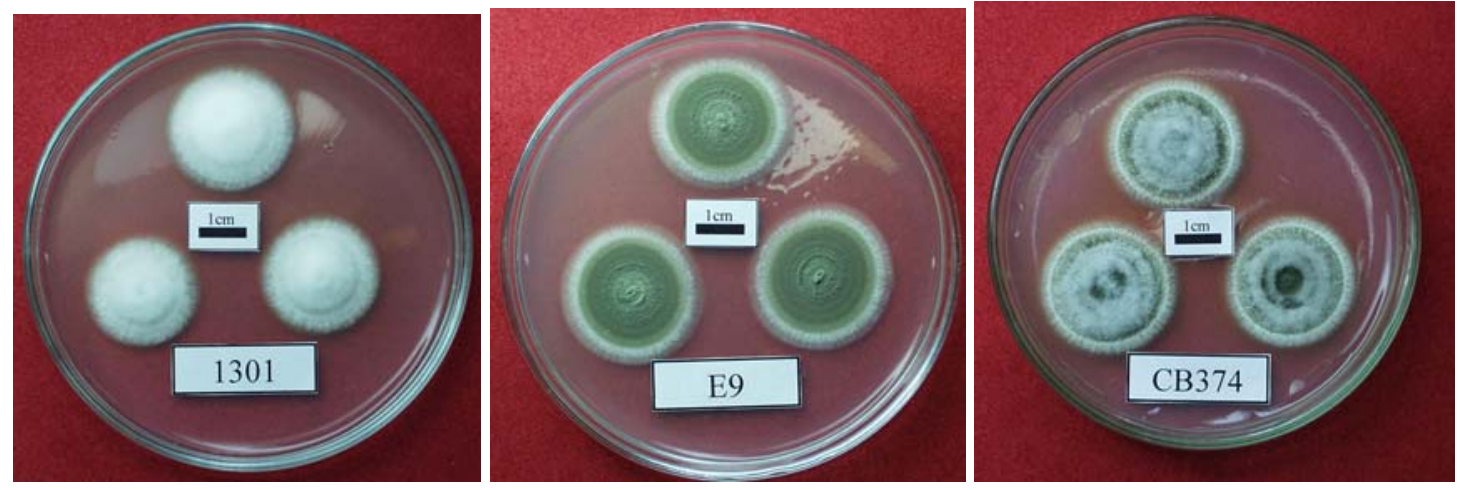

Figura 12 - Características morfológicas de colônias de Metarhizium anisopliae isolados ESALQ 1301, ESALQ E9 e IBCB-374 com oito dias de incubação $\left(26 \pm 1^{\circ} \mathrm{C} ; 80 \pm 5 \% ; 12\right.$ horas de fotofase)

Tigano-Milani et al. (1995a) observaram que o genótipo de um isolado parece estar mais relacionado com o hospedeiro do que com o local de origem geográfica. Esses autores relataram que o solo apresenta muitos isolados de M. anisopliae com grande variabilidade genética em uma área específica. Estudos realizados por Fungaro et al. (1996) com isolados de M. anisopliae var. anisopliae, também demonstraram, com o emprego do método de RAPD, que a diversidade entre os isolados obtidos de Deois flavopicta é 
muito menor que aquela encontrada entre isolados provenientes de solo, sugerindo um certo grau de especificidade hospedeira. Entretanto, no presente estudo não se observou um padrão específico de agrupamento entre isolados oriundos da mesma região ou hospedeiro. Assim, a diversidade genética parece ser independente do local de origem do fungo, como seria esperado com um patógeno que, em geral, mostra alto grau de especialização ao hospedeiro (Cobb \& Clarkson, 1993). O mesmo foi observado por Fegan et al. (1993) que, estudando isolados de M. anisopliae var. anisopliae, verificaram que os mesmos foram extremamente diferentes comparando em nível de DNA, utilizando RAPD. Bidochka et al. (1994) trabalhando com M. flavoviridae e M. anisopliae e Cravanzola et al. (1997) com Beauveria bassiana também obtiveram resultados semelhantes.

Os isolados IBCB-348 e IBCB-374, por exemplo, provenientes de mesmo local e hospedeiro, apresentaram índice de similaridade de 0,72, sendo colocados em grupos diferentes. Vargas et al. (2003) caracterizando isolados de Nomuraea rileyi observaram alta homologia entre os isolados testados apesar de serem de locais e hospedeiros distintos, ou seja, não encontraram relação entre os parâmetros virulência, atividade proteolítica ou quitinolítica e análise de RAPD. Essa mesma constatação foi feita por Leal et al. (1994b) para M. anisopliae, Tigano-Milani et al. (1995b) para Paecilomyces fumosoroseus e por Driver et al. (2000) para M. anisopliae, M. flavoviridae e M. album. Fegan et al. (1993) sugerem que marcadores morfológicos empregados na taxonomia de M. anisopliae var. anisopliae falham na definição de um grupo geneticamente uniforme e que isolados com genomas exibindo mais de $70 \%$ de dissimilaridade têm sido incluídos na 
subespécie M. anisopliae var. anisopliae. Dessa maneira, os autores concluem que não se pode fazer associação entre os isolados de $M$. anisopliae e seu local de origem ou hospedeiro. Para Cobb \& Clarkson (1993) a explicação para isso seria o modo de reprodução de M. anisopliae, pois, apesar da recombinação genética pelo ciclo parassexual ter sido demonstrada para esse fungo toda a recombinação parassexual em populações selvagens de Metarhizium ainda não é conhecida. A incompatibilidade somática pode prevenir a formação de heterocários estáveis entre isolados que diferem significativamente em seus genótipos, resultando na existência de grande número de clones isolados reprodutivamente.

Fungos assexuais geralmente possuem menor diversidade quando comparados aos microrganismos que se reproduzem sexuadamente por causa da ausência de recombinação genética, exceto em casos em que a hibridização somática ou o ciclo parassexual compense essa ausência. $O$ modo de reprodução clonal, na maioria dos casos, limita os microrganismos assexuais a ter como variação genética apenas mutações. Porém, a vasta distribuição espacial e a alta gama de hospedeiros dos deuteromicetos sugerem que a despeito da reprodução ser assexuada, existe alta variabilidade genética nessas espécies. A observação comum é que a variabilidade genética está presente e o polimorfismo presente é variável (Castrillo \& Brooks, 1998).

Variações fenotípicas como, por exemplo, variação na patogenicidade e variações morfológicas, que foram observadas nos isolados de M. anisopliae associados a M. fimbriolata, foram demonstradas com a presença de variabilidade genética como foi determinado pelo RAPD. Esse 
polimorfismo genético pode ter sido acumulado, ao longo do tempo, por mutações ou, possivelmente, por recombinação parassexual que é mantida pela seleção natural ou simplesmente pelo modo de reprodução do fungo. Esse polimorfismo genético dá ao fungo a plasticidade para se adaptar e sobreviver em um meio heterogêneo. Mesmo sendo, a maioria dos isolados testados, provenientes da mesma espécie de hospedeiro, em parte de sua vida o fungo permanece no solo, na forma de esporos, e, para sua sobrevivência quando a população dos insetos é baixa, ele possivelmente compete com outros microrganismos.

Alves et al. (1983) observaram uma alta especificidade de isolados de M. anisopliae de padrão eletroforético semelhante para M. posticata, encontrados em $97 \%$ das amostras coletadas em campos de cana-de-açúcar no nordeste brasileiro.

Nos testes de patogenicidade com M. fimbriolata observou-se grande variação na porcentagem de mortalidade para os 20 isolados, evidenciando a existência de variabilidade genética em relação a esse parâmetro, mesmo sendo a maioria dos isolados provenientes de insetos de mesma espécie. Isolados pertencentes ao grupo $A$ apresentaram mortalidades médias que variaram de 38,6 a $59,5 \%$. Dentro do grupo $B$, as mortalidades médias variaram de 10,5 a $59,7 \%$. Para os isolados pertencentes ao subgrupo B2, a mortalidade média de ninfas foi mais variável, sendo de $11,5 \%$ para o isolado ESALQ PL26 a 59,7\% para o isolado IBCB-384 ao quinto dia após a inoculação (Figura 3). Esses resultados refletem a grande diferença entre os nove isolados que não configuram o grupo $A$ e subgrupo B1. 
Com a análise de RAPD o agrupamento dos isolados (Figura 11) não refletiu a similaridade obtida com os testes de patogenicidade a ninfas de M. fimbriolata. Os dois isolados mais patogênicos (IBCB-384 e ICBC-348 com 59,7 e $59,5 \%$ de mortalidade corrigida, respectivamente) ficaram colocados em grupos fenéticos diferentes. Resultados semelhantes foram observados por Luz et al. (1998) testando a patogenicidade de Beauveria bassiana a Triatoma infestans e por Devi et al. (2001) testando a virulência de B. bassiana a Chilo partellus.

Todos os grupos de pesquisa que tem usado marcadores de RAPD para análise de isolados de M. anisopliae tem demonstrado altos graus de variabilidade genotípica. Nenhuma correlação entre genótipo e espécie de insetos hospedeiros foi, entretanto, detectada (Mavridou \& Typas, 1998).

Riba et al. (1986) comparando 96 isolados de M. anisopliae quanto ao tamanho dos conídios, sua virulência a Ostrinia nubialis e o perfil de algumas de suas isoenzimas concluíram que existe maior variação entre os isolados de M. anisopliae var. anisopliae quanto à virulência, hospedeiro original e isoenzimas, do que nos isolados de M. anisopliae var. majus.

A identificação positiva do isolado utilizado em aplicações de campo, que determinam sua eficiência no controle de determinada praga, pode ser realizada de forma prática usando-se métodos genéticos. A tipagem molecular também pode ser utilizada na caracterização precisa do material presente em coleções de entomopatógenos. A correlação entre a tipagem molecular e a patogenicidade de M. anisopliae para determinada praga, bem como entre outros parâmetros morfológicos e biológicos do 
fungo, pode ser útil para o "screening" de isolados promissores no desenvolvimento de programas de controle microbiano. 


\section{CONCLUSÕES}

- Todos os isolados de Metarhizium anisopliae são patogênicos para Mahanarva fimbriolata,

- A manutenção das ninfas de Mahanarva fimbriolata em raízes de mudas de cana-de-açúcar é um método eficiente para bioensaios de patogenicidade com Metarhizium anisopliae;

- Ocorrem diferenças morfológicas entre os isolados de Metarhizium anisopliae em relação às dimensões dos conídios, coloração $e$ crescimento das colônias;

- Mais de 50\% dos isolados de Metarhizum anisopliae testados apresentam RNA de fita dupla que pode indicar a presença de vírus;

- Verifica-se alta similaridade entre os isolados não havendo um padrão específico de agrupamento entre aqueles oriundos da mesma região ou hospedeiro:

- Pela caracterização genética e morfológica os isolados pertencem à espécie Metarhizium anisopliae var. anisopliae. 


\section{REFERÊNCIAS BIBLIOGRÁFICAS}

ALMEIDA, J.E.M. Avaliação de fungos entomopatogênicos visando ao controle do cupim subterrâneo Heterotermes tenuis (Hagen, 1858) (Isoptera: Rhinotermitidae). Piracicaba, 1994. 105p. Dissertação (Mestrado) - Escola Superior de Agricultura "Luiz de Queiroz", Universidade de São Paulo.

ALMEIDA, J.E.M.; ALVES, S.B.; PEREIRA, R.M. Selection of Beauveria spp. isolates for control of the termite Heterotermes tenuis (Hagen, 1858). Journal of Applied Entomology, v.121, p.538-543, 1997.

ALVES, S.B. Fungos entomopatogênicos. In: ALVES, S.B. (Ed.). Controle microbiano de insetos. Piracicaba: Fealq, 1998. cap.11, p.289-382.

ALVES, S.B.; PEREIRA, R.M.P. Produção de Metarhizium anisopliae (Metsch.) Sorok e Beauveria bassiana (Bals.) Vuill. em bandejas. Ecossistema, v.14, p.188-192, 1989. 
ALVES, S.B.; LECUONA, R.E. Epizootiologia aplicada ao controle microbiano de insetos. In: ALVES, S.B. (Ed.). Controle microbiano de insetos. Piracicaba: Fealq, 1998. cap.5, p.97-169.

ALVES, S.B.; MACHADO NETO, R.; MACEDO, N.; ALMEIDA, L.C. Widespread occurrence of Metarhizium anisopliae (Metschnikoff) Sorok. (standard A) on Mahanarva posticata (Stal.) in Brazil. Entomology Newsletter, v.15, p.6, 1983.

ALVES, S.B.; SILVEIRA NETO, S.; HADDAD, L.M.; SOSA GOMES, D.R. Separação de isolados de Metarhizium anisopliae (Metsch.) Sorok. através da análise fenética. Anais da Sociedade Entomológica de Brasil, v.15, p.81-92, 1986.

AZZI, G.M.; DODSON, A.K. Infestação de cigarrinha-da-raiz em canaviais de Piracicaba-SP (Mahanarva fimbriolata Stal). Brasil Açucareiro, n.5, p.36-42, 1971.

BALBO JUNIOR, W.; MOSSIM, G.C. Ocorrência e tentativa de controle de pragas em cana-de-açúcar na Usina Santo Antônio. In: SEMANA DA CANA-DE-AÇÚCAR DE PIRACICABA, 4., Piracicaba, 1999. Piracicaba: AFOCAPI, 1999. p.40-42. 
BAUMANN, R.; SCHUBERT, R.; HEITLAND, W.; AUGER-ROZENBERG, A.A.; FAIVRE-RIMPANT, P.; MÜLLER-STARCK, G. Genetic diversity within and among populations of Diprion pini (Hym., Diprinidae) determined by random amplified polymorphic DNA-polymerase chain reaction of haploid males. Journal of Applied Entomology, v.127, p.258$264,2003$.

BERRETTA, M.F.; LECUONA, R.E.; ZANDOMENI, R.O.; GRAU, O. Genotyping isolates of the entomopathogenic fungus Beauveria bassiana by RAPD with fluorescent labels. Journal of Invertebrate Pathology, v.71, p.145-150, 1998.

BIDOCHKA, M.J.; MCDONALD, M.A.; St. LEGER, R.J.; ROBERTS, D.W. Differentiation of species and strins of entomopathogenic fungi by random amplification of polymorphic DNA (RAPD). Current Genetics, v.25, p.107-113, 1994.

BOGO, M.R.; QUEIROZ, M.V.; SILVA, D.M.; GIMÉNEZ, M.P.; AZEVEDO, J.L.; SCHRANK, A. Double-stranded RNA and isometric virus-like particles in the entomopathogenic fungus Metarhizium anisopliae. Mycological Research, v.100, n.12, p.1468-1472, 1996. 
BOTELHO, P.S.M.; MENDES, A. de C.; MACEDO, N.; SILVEIRA NETO, S. Atração da cigarrinha da raiz Mahanarva fimbriolata (Stal, 1854) (Homoptera, Cercopidae), por luzes de diferentes comprimento de onda. Brasil Açucareiro, v.88, n.3, p.37-42, 1976.

BRAGA, G.U.L. Caracterização fisiológica e molecular de linhagens de Metarhizium anisopliae. Campinas, 1997. 128p. Tese (Doutorado) Universidade de Campinas.

CASTRILLO, L.A.; BROOKS, W.M. Differentiation of Beauveria bassiana isolates from the darkling beetle, Alphitobius diaperinus, using isozyme and RAPD analyses. Journal of Invertebrate Pathology, v.72, p.190196, 1998.

CHEN, J-W.; LIU, B-L.; TZENG, Y-M. Purification and quantification of destruxins $A$ and $B$ from Metarhizium anisopliae. Journal of Chromatography A, v.830, p.115-125, 1999.

COBB, B.D.; CLARKSON, J.M. Detection of molecular variation in the insect pathogenic fungus Metarhizium using RAPD-PCR. FEMS Microbiology Letters, v.112, p.319-324, 1993.

COTTAS, M.P.; RAMIRO, Z.A.; OLIVEIRA, D.A.; FRANCO, R.M. Análise dos métodos de amostragens utilizados em levantamentos de cigarrinhas das pastagens. Biológico, v.49, n.6, p.153-161, 1983. 
CRAVANZOLA, F.; PIATTI, P.; BRIDGE, P.D.; OZINO, O.I. Detection of genetic polymorphism by RAPD-PCR in strins of the entomopathogenic fungus Beauveria brongniartii isolated from the European cockchafer (Melolontha spp.). Letters in Applied Microbiology, v.25, p.289-294, 1997.

DESTÉFANO, R.H.R.; DESTÉFANO, S.A.L.; MESSIAS, C.L. Detection of Metarhizium anisopliae (Lepidoptera, Pyralidae) using specific primers. Genetics and Molecular Biology, v.27, n.2, p.245-252, 2004.

DEVI, K.U.; PADMAVATHI, J.; SHARMA, H.C.; SEETHARAMA, N. Laboratory evaluation of the virulence of Beauveria bassiana isolates to the sorghum shoot borer Chilo partellus Swinhoe (Lepidoptera: Pyralidae) and their characterization by RAPD-PCR. World Journal of Microbiology \& Biotechnology, v.17, p.131-137, 2001.

DINARDO-MIRANDA, L.L. O papel da retirada da palha no manejo da cigarrinha das raízes. STAB - Açúcar, Álcool e Subprodutos, v.20, n.5, p.23, Maio/Jun. 2002.

DINARDO-MIRANDA， L.L.; FERREIRA， J.M.G.; CARVALHO, P.A.M. Influência da época de colheita e do genótipo de cana-de-açúcar sobre a infestação de Mahanarva fimbriolata (Stal) (Hemiptera: Cercopidae). Neotropical Entomology, v.30, n.1, p.145-149, Mar. 2001. 
DINARDO-MIRANDA, L.L.; COELHO, A.L.; FERREIRA, J.M.G. Influência da época de aplicação de inseticidas no controle de Mahanarva fimbriolata (Stal) (Hemiptera: Cercopidae), na qualidade e na produtividade da canade-açúcar. Neotropical Entomology, v.33, n.1, p.91-98, 2004a.

DINARDO-MIRANDA， L.L.; FIGUEIREDO， P.; LANDELLI， M.G.A.; FERREIRA, J.M.G.; CARVALHO, P.A.M. de Danos causados pelas cigarrinhas das raízes (Mahanarva fimbriolata) a diversos genótipos de cana-de-açúcar. STAB - Açúcar, Álcool e Subprodutos, v.17, n.5, p.48-52, Maio/Jun. 1999.

DINARDO-MIRANDA, L.L.; VASCONCELOS, A.C.M.; FERREIRA, J.M.G.; GARCIA JÚNIOR, C.A.; COELHO, A.L.; GIL, M.A. Eficiência de Metarhizium anisopliae (Metsch.) no controle de Mahanarva fimbriolata (Stal) (Hemiptera: Cercopidae) em cana-de-açúcar. Neotropical Entomology, v.33, n.6, p.743-749, Nov./Dec. 2004b.

DRIVER, F.; MILNER, R.J.; TRUEMAN, W.H. A taxonomic revision of Metarhizium based on a phylogenetic analysis of rDNA sequence data. Mycological Research, v.104, n.2, p.134-150, 2000.

EL-KADI, M.K. Novas perspectivas no controle de cigarrinhas. In: CONGRESSO BRASILEIRO DE ENTOMOLOGIA, 4., Goiânia, 1977. CONFERÊNCIAS, PALESTRAS E EXPOSIÇÕES. Goiânia: SEB, p.58-67, 1977. 
FEGAN, M.; MANNERS, J.M.; MACLEAN, D.J.; IRWIN, J.A.G.; SAMUELS, K.D.Z.; HOLDOM, D.G.; LI, D.P. Random amplified polymorphic DNA markers reveal a high degree of genetic diversity in the entomopathogenic fungus Metarhizium anisopliae var. anisopliae. Journal of General Microbiology, v.139, p.2075-2081, 1993.

FENNAH, R.G. Revisionary notes on the new world generaof cercopid froghoppers (Homoptera: Cercopoidea). Bulletin of Entomological Research, v.58, n.1, p.165-190, 1968.

FERNANDES, P.M.; ALVES, S.B. Controle de Cornitermes cumulans (Kollar, 1832) (Isoptera: Termitidae) com Beauveria bassiana (Bals.) Vuill.; e Metarhizium anisopliae (Metsch.) Sorok. em condições de campo. Anais da Sociedade Entomológica do Brasil v.20, p.45-49, 1991.

FERREIRA, M.E.; GRATTAPAGLIA, D. Introdução ao uso de marcadores RAPD e RFLP em análise genética. Brasília: EMBRAPA, 1995. 220p.

FREIRE, A.M.; SOUTO, C.E.R.; MARQUES, E.J.; Combate biológico das cigarrinhas da cana-de-açúcar. Brasil Açucareiro, v.71, n.4, p.41-44, 1968. 
FUNGARO, M.H.P.; VIEIRA, M.L.C.; PIZIRANI-KLEINER, A.A.; AZEVEDO, J.L. de Diversity among soil and insect isolates of Metarhizium anisopliae var. anisopliae detected by RAPD. Letters in Applied Microbiology, v.22, p.389-392, 1996.

GALLO, D.; NAKANO, O.; SILVEIRA NETO, S.; CARVALHO, R.P.L.; BAPTISTA, G.C. de; PARRA, J.R.P.; ZUCCHI, R.A.; ALVES, S.B.; VENDRAMIM, J.D.; MARCHINI, L.C.; LOPES, J.R.S.; OMOTO, $C$. Entomologia Agrícola, Piracicaba: Fealq, 2002. 920p.

GUAGLIUMI, P. As cigarrinhas dos canaviais no Brasil. Brasil Açucareiro, v.72, n.3, p.34-43, 1968.

GUAGLIUMI, P. Pragas da cana-de-açúcar: Nordeste do Brasil. Rio de Janeiro: Instituto do Açúcar e do Álcool, 1973. p.69-204. (Coleção Canavieira, 10).

HALLSWORTH, J.E.; MAGAN, N. Water and temperature relations of growth of the entomogenous fungi Beauveria bassiana, Metarhizium anisopliae and Paecilomyces farinosus. Journal of Invertebrate Pathology, v.74, p.261-266, 1999. 
HEGEDUS, D.D.; KHACHATOURIANS, G.G. Identification of molecular variants in mitochondrial DNAs of members of the genera Beauveria, Verticillium, Paecilomyces, Tolypocladium, and Metarhizium. Applied and Environmental Microbiology, v.59, n.12, p.4283-4288, Dec. 1993.

HEGEDUS, D.D.; KHACHATOURIANS, G.G. Identification and differentiation of the entomopathogenic fungus Beauveria bassiana using Polymerase Chain Reaction and single-strain conformation polymorphism analysis. Journal of Invertabrate Pathology, v.67, p.289-299, 1996a.

HEGEDUS, D.D.; KHACHATOURIANS, G.G. Detection of the entomopathogenic fungus Beauveria bassiana within infected migratory grasshoppers (Melanoplus sanguinipes) using Polymerase Chain Reaction and DNA probe. Journal of Invertabrate Pathology, v.67, p.21-27, 1996b.

HSIAO, Y.M.; KO, J.L. Determination of destruxins, cyclic peptide toxins, produced by different strains of Metarhizium anisopliae and their mutants induced by ethyl methane sulfonate and ultraviolet using HPLC method. Toxicon, v.39, p.837-841, 2001.

IBGE (http: www.ibge.gov.br) (17 nov. 2004). 
INGLIS, P.W.; ARAGÃO, F.J.L.; MAGALHÃES, B.P.; VALADARES-INGLIS, M.C. Biolistic co-transformation of Metarhizium anisopliae var. acridum strain CG423 with green fluorescent protein and resistance to glufosinate ammonium. FEMS Microbiology Letters, v.191, p.249-254, 2000.

JEFFS, L.B.; XAVIER, I.J.; MATAI, R.E.; KHACHATOURIANS, G.G. Relationships between fungal spore morphologies and surface properties for entomopathogenic members of the genera Beauveria, Metarhizium, Paecilomyces, Tolypocladium and Verticillium. Canadian Journal of Microbiology, v.45, n.11, p.936-948, Nov. 1999.

JOSHI, L.; St. LEGER, R.J.; ROBERTS, D.W. Isolation of a CDNA encoding a novel subtilisin-like protease $(\operatorname{Pr} 1 B)$ from the entomopathogenic fungus, Metarhizium anisopliae using differential display -RT - PCR. Gene, v.197, p.1-8, 1997.

KANG, S.C.: PARK, S.; LU, D.G. Purification and characterization of a novel chitinase from the entomopathogenic fungus, Metarhizium anisopliae. Journal of Invertebrate Pathology, v.73, p.276-281, 1999.

LEAL, S.C.M.; BERTIOLI, D.J.; BUTT, T.M.; PEBERDY, J.F. Characterization of isolates of the entomopathogenic fungus Metarhizium anisopliae by RAPD-PCR. Mycological Research, v.98, n.9, p.1077-1081, 1994a. 
LEAL, S.C.M.; BERTIOLI, D.J.; BALL, B.V.; BUTT, T.M. Presence of doublestranded RNA sans virus-like particles in the entomopathogenicus fungus Metarhizium anisopliae. Biocontrol Science and Technology, v.4, p.89$94,1994 b$.

LEAL-BERTIOLI, S.C.M.; BUTT, T.M.; PEBERDY, J.F.; BERTIOLI, D.J. Genetic exchange in Metarhizium anisopliae strains co-infecting Phaedon cochleariae is revealed by molecular markers. Mycological Research, v.104, n.4, p.409-414, Apr. 2000.

LOPES, R.B. Seleção de fungos entomopatogênicos e controle de Frankliniella occidentalis (Tysanoptera: Thripidae). Piracicaba, 1999. 72p. Dissertação (Mestrado) - Escola Superior de Agricultura "Luiz de Queiroz", Universidade de São Paulo.

LOUTELIER, C.; CHERTON, J-C.; LANGE, C.; TRARIS, M.; VEY, A. Studies on the dynamics of the productions of destruxins by Metarhizium anisopliae. Direct high-performance liquid chromatographic and fast atom bombardment mass spectrometric analysis correlated with biological activity tests. Journal of Chromatography A, v.738, p.181189, 1996. 
LUZ, C.; TIGANO, M.S.; SILVA, I.G.; CORDEIRO, C.M.T.; ALJANABI, S.M. Selection of Beauveria bassiana and Metarhizium anisopliae isolates to control Triatoma infestans. Memórias do Instituto Oswaldo Cruz, v.96, n.6, p.839-846, Nov./Dez. 1998.

MACEDO, N.; MACEDO, D. As pragas de maior incidência nos canaviais e seus controles. Visão Agrícola, v.1, p.38-46, 2004.

MACEDO, N.; CAMPOS, M.B.S.; ARAÚJO, J.R. Insetos nas raízes e colo da planta, perfilhamento e produtividade em canaviais colhidos com e sem queima. STAB - Açúcar, Álcool e Subprodutos, v.15, n.3, p.18-21, 1997.

MACEDO, N.; MENDES, A.C.; BOTELHO, P.S.M.; MAGRO, J.A. Metarhizium anisopliae (Metch) Sorokin no controle da cigarrinha da raiz (Mahanarva fimbriolata Stal) na cultura da cana-de-açúcar. Brasil açucareiro, v.2, p.16-19, Ago. 1977.

MARTINS, M.K.; FURLANETO, M.C.; SOSA-GÓMEZ, D.R.; FARIA, M.R.; FUNGARO, M.H.P. Double-stranded RNA in the entomopathogenic fungus Metarhizium anisopliae. Current Genetics, v.36, p.94-97, 1999.

MAVRIDOU, A.; TYPAS, M.A. Intrasecific polymorphism in Metarhizium anisopliae var. anisopliae revealed by analysis of rRNA gene complex and m+DNA RFLPs. Mycological Research, v.102, n.10, p.1233-1241, 1998. 
MENDES, A.C. Influence of climatic factors on the populations of sugarcane moth borer, Diatraea saccharalis (Fabr.), and root froghopper, Mahanarva fimbriolata (Stal). São Paulo - Brasil. ISSCT Entomology Newsletter, v.4, n.13, 1978.

MENDONÇA, A.F.; BARBOSA, G.V.S.; MARQUES, E.J. As cigarrinhas da cana-de-açúcar (Hemiptera: Cercopidae) no Brasil. In: MENDONÇA, A.F. (Ed.). Pragas da cana-de-açúcar. Maceió: Insetos \& CIA, 1996. p.171-192, 1996.

MILNER, R.J. The selection of strains of Metarhizium anisopliae for control of australian sugar-cane white grubs. In: GLARE, T.R.; JACKSON, T.A. (Ed.). Use of pathogens in scarab pest management. England: Athenacum Press, 1992. 298p.

MOINO JÚNIOR, A. Utilização de Metarhizium anisopliae (Metsch.) Sorok. e Beauveria bassiana (Bals.) Vuill. para o controle de pragas de grãos armazenados. Piracicaba, 1993. 100p. Dissertação (Mestrado) - Escola Superior de Agricultura "Luiz de Queiroz", Universidade de São Paulo.

MOINO JÚNIOR, A.; ALVES, S.B.; PEREIRA, R.M. Efficacy of Beauveria bassiana (Balsamo) Vuillemin isolates for control of stored-grain pests. Journal of Applied Entomology, v.122, p.301-305, 1998. 
OBORNÍK, M.; KLÍC, M.; ZIZKA, L. Genetic variability and phylogeny inferred from random amplified polymorphic DNA data reflect life strategy of entomopathogenic fungi. Canadian Journal of Botany, v.78, p.1150-1155, 2000.

PANTOU, M.P.; MAVRIDOU, A.; TYPAS, M.A. IGS sequence variation, group-I introns and the complete nuclear ribossomal DNA of the entomopathogenic fungus Metarhizium: excellent tools for isolate detection and phylogenetic analysis. Fungal Genetics and Biology, v.38, p.159-174, 2003.

PEDRAS, M.S.C.; ZAHARIA, L.I.; WARD, D.E. The destruxins: sunthesis, biosynthesis, biotransformation, and biological activity. Phytochemistry, v.59, p.579-596, 2002.

PEREIRA, R.M.; ALVES, S.B. Produção de fungos entomopatogênicos. In: ALVES, S.B. (Ed.). Controle microbiano de insetos. Piracicaba: Fealq, 1998. cap.27, p.845-869.

POTTERAT, O.; WAGNER, K. HAAG, H. Liquid chromatography electrospray time-of-flight mass spectrometry for on-line accurate mass determination and identification of cyclodepsipeptides in a crude extract of the fungus Metarhizium anisopliae. Journal of Chromatography A, v.872, p.85-90, 2000. 
RAEDER, U.; BRODA, P. Rapid preparation of DNA from filamentous fungi. Letters in Applied Microbiology, v.1, n.1, p.17-20, 1985.

RAKOTONIRAINY, M.S.; CARIOU, M.L.; BRYGOO, Y.; RIBA, G. Phylogenetic relationship within the genus Metarhizium based on 285 rRNA sequences and isozyme comparison. Mycological Research, v.98, n.2, p.225-230, 1994.

RAMOS, E.Q. Seleção de isolados de fungos entomopatogênicos para o controle de Bemisia tabaci Biótipo "B". Piracicaba, 2001. 57p. Dissertação (Mestrado) - Escola Superior de Agricultura "Luiz de Queiroz", Universidade de São Paulo.

RIBA, G.; BOUVIER-FOURCADE, I.; CAUDAL, A. Isoenzymes polymorphism in Metarhizium anisopliae (Deteromycotina: Hyphomycetes) entomogenous fungi. Mycopathologia, v.96, p.161-169, 1986.

RIBEIRO, B.M.; SOUZA, M.L.; KITAJIMA, E.W. Taxonomia, caracterização molecular e bioquímica de vírus de insetos. In: ALVES, S.B. (Ed.). Controle microbiano de insetos. Piracicaba: Fealq, 1998. cap.14, p.481507. 
ROBERTS, D.W. Toxins from the entomogenous fungus Metarhizium anisopliae: isolation of destruxins from submerged cultures. Journal of Invertebrate Pathology, v.14, p.82-88, 1969.

ROBERTS, D.W.; GUPTA, S.; St. LEGER, R.J. Metabolite production by entomopathogenic fungi. Pesquisa Agropecuária Brasileira, v.27, p.325347, 1992.

ROSSI, L.S. Seleção de fungos entomopatogênicos e infecção de Hirsutella sp. em Brevipalpus phoenicis (Geijskes, 1939). Piracicaba, 2002. 92p. Dissertação (Mestrado) - Escola Superior de Agricultura "Luiz de Queiroz", Universidade de São Paulo.

SCHNEIDER-ORELLI, O. Entomologisches Praktikum: Einfuehrung in die land - und forstwirtschaftliche Insektekunde. Aarau: Zweite Aufl., 1947. 237p.

SOSA GOMES, D.R.; ALVES, S.B. Caracterización de once aislamientos de Metarhizium anisopliae (Metsch.) Sorok. 1. Estandarización, virulencia y actividad enzimática. CIRPON Revista Investigativa, v.1, p.83-102, 1983.

SOSA-GÓMEZ, D.R.; PEREIRA, R.M.; ALVES, S.B. Impacto ambiental de entomopatógenos. In: ALVES, S.B. (Ed.). Controle microbiano de insetos. Piracicaba: Fealq, 1998. cap.37, p.1075-1095. 
St. LEGER, L.J.; STAPLES, R.C.; ROBERTS, D.W. Entomopathogenic isolates of Metarhizium anisopliae, Beauveria bassiana, and Aspergillus flavus produce multiple extracellular chitinase isozymes. Journal of Invertebrate Pathology, v.61, p.81-84, 1993.

St. LEGER, R.J.; GOETTEL, M.; ROBERTS, D.W.; STAPLES, R.C. Prepenetration events during infection of host cuticle by M. anisopliae. Journal of Invertebrate Pathology, v.58, p.168-179, 1991.

St. LEGER, L.J.; MAY, B.; ALLEE, L.L.; FRANK, D.C.; STAPLES, R.C.; ROBERTS, D.W. Genetic differences in allozymes and in formation of infection structures among isolates of the entomopathogenic fungus Metarhizium anisopliae. Journal of Invertebrate Pathology, v.60, p.89$101,1992$.

SUZUKI, A.; KAWAKAMI, K.; TAMURA, S. Isolation and structure elucidation of three new insecticidal cyclodepsipeptides, destruxins $C$ and $D$ and desmethyldestruxin $B$, produced by Metarhizium anisopliae. Biological Chemistry, v.34, n.5, p.813-816, 1970.

SUZUKI, A.; KAWAKAMI, K.; TAMURA, S. Detection of destruxins in silkworm larvae infected with Metarhizium anisopliae. Biological Chemistry, v.35, n.10, p.1641-1643, 1971. 
TAMAI, M.A. Avaliação de fungos entomopatogênicos para o controle de Tetranychus urticae Koch. Piracicaba, 1998. 86p. Dissertação (Mestrado) - Escola Superior de Agricultura "Luiz de Queiroz", Universidade de São Paulo.

TIGANO-MILANI, M.S.; GOMES, A.C.M.M.; SOBRAL, B.W.S. Genetic variability among Brazilian isolates of the entomopathogenic fungus Metarhizium anisopliae. Journal of Invertebrate Pathology, v.65, p.206-210, 1995a.

TIGANO-MILANI, M.S.; HONEYCUTT, R.J.; LACEY, L.A.; ASSIS, R.; MCCLELLAND, M.; SOBRAL, B.W.S. Genetic variability of Paecilomyces fumosoroseus isolates revealed by molecular markers. Journal of Invertebrate Pathology, v.65, p.274-282, $1995 b$.

THOMAS, S.R.; ELKINTON, J.S. Pathogenicity and virulence. Journal of Invertebrate Pathology, v.85, p.146-151, 2004.

TULLOCH, M. The genus Metarhizium. Transactions of the British Mycological Society, v.66, p.407-411, 1976.

VARGAS, L.R.B.; ROSSATO, M.; RIBEIRO, R.T.S.; BARROS, N.M. Characterization of Nomuraea rileyi strains using polymorphic DNA, virulence and enzyme activity. Brazilian Archives of Biology and Technology, v.46, n.1, p.13-18, Jan. 2003. 
WANG, C.; TYPAS, M.A.; BUTT, T.M. Detection and characterization of pr1 virulent gene deficiencies in the insect pathogenic fungus Metarhizium anisopliae. FEMS Microbiology Letters, v.213, p.251-255, 2002.

WELSH, J.; MCCLELLAND, M. Fingerprinting genomes using PCR with arbitrary primers. Nucleic Acids Research, v.18, n.24, p.7213-7218, 1990.

YIP, H.Y.; RATH, A.C.; KOEN, T.B. Characterization of Metarhizium anisopliae isolates from Tasmanian pasture soils and their pathogenicity to redheaded cockchafer (Coleoptera: Scarabeidae: Adoryphorus couloni). Mycological Research, v.96, n.2, p.92-96, 1992.

ZIMMERMAN, G. The entomopathogenic fungus Metarhizium anisopliae and its potencial as a biocontrol agent. Pesticide Science, v.37, p.375-379, 1993. 